\title{
LITERATURA POLITYCZNA W SIEDEMNASTOWIECZNYCH KSIĘGOZBIORACH SZLACHTY KORONNEJ W ŚWIETLE PRODUKCJI WYDAWNICZEJ KRAJOWYCH OFICYN DRUKARSKICH Z LAT 1501-1732
}

Inwentarze księgozbiorów prywatnych stanowią ważne źródło do badań czytelnictwa pojmowanego jako proces recepcji spisanego dorobku kultury przez kręgi publiczności czytającej. Pojawia się tutaj problem rekonstrukcji repertuaru wydawniczego jako jednego z głównych czynników - obok sieci księgarskiej, zbiorów bibliotek instytucjonalnych i prywatnych - wpływających na dostępny w danym czasie i miejscu zasób piśmiennictwa. Kwestia podaży ksiażek jest o tyle istotna, że "wszelkie wybory lekturowe są dokonywane tylko wśród fizycznie osiagalnych pozycji i tylko w tym kontekście mogą być rozważane". Owe wybory najdobitniej dokumentują właśnie inwentarze księgozbiorów prywatnych ${ }^{1}$.

Dane dotyczące repertuaru wydawniczego oraz zespół inwentarzy traktowanych jako źródła masowe, pozwalają na przeprowadzenie badań kwantytatywnych, dzięki którym można określić stopień i rodzaj zależności zachodzących między repertuarem wydawniczym a strukturą ilościowo-tematyczną księgozbiorów. Opierając się na analizie statystycznej oraz treściowej danych, można także podjąć próbę określenia kanonów lekturowych charakterystycznych dla danej epoki oraz preferencji indywidualnych czytelników.

Z zagadnieniami repertuaru wydawniczego (a raczej podaży książek) i analizy zawartości księgozbiorów wiąże się kwestia funkcji literatury omawianego typu.

Niniejszy artykuł oparty na danych zawartych w maszynopisie pracy magisterskiej Rola i funkcje książki polityczno-prawnej w środowisku szlachty koronnej w latach 1587-1732 $2^{2}$ - stanowi próbę opracowania wyżej wymienionych problemów w odniesieniu do literatury politycznej i jej miejsca w siedemnastowiecznych księgozbiorach szlacheckich. Badaniami objęto wszystkie opublikowane inwentarze księgozbiorów, których właścicieli można zaliczyć do stanu szlacheckiego. Zasięg terytorialny badań nad księgozbiorami wyznaczają granice Korony, zakres chronologiczny lata 1587-1732. Przyjęte w ten sposób (umowne) daty, wyznaczają pewną całość w dziejach kultury Rzeczypospolitej określaną w literature przedmiotu mianem epoki Baroku lub XVII wieku. Okres ten, otwiera początek panowania Zygmunta III (lata 1587-1588), kiedy to załamuje się stopniowo ruch egzekucyjny szlachty rozwija się kontrreformacja, pojawiają się pierwsze symptomy przemian ustrojowych, prowadzących do tego, że model ustrojowy Rzeczypospolitej „musiał 
się wyrodzić, wynaturzyć, przejść daleko idące przeobrażenia by w końcu stać się jedynie powłoką ideologiczną, teorią bez pokrycia w praktyce" ${ }^{\text {"3 }}$. Jako datę zamykająca epoke przyjęto rok ogłoszenia drukiem pierwszego tomu zbioru ustaw $i$ konstytucji Rzeczypospolitej opracowanego przez Stanisława Konarskiego, dzieła, które symbolizuje początek ruchu oświeceniowego w latach trzydziestych XVIII wieku, zmierzającego do przeprowadzenia reform ustrojowych w państwie ${ }^{4}$.

W oparciu o wyżej wymienione kryteria wykorzystano w pracy dane dotyczące następujących księgozbiorów:

- Stanisława Sapińskiego, szlachcica wielkopolskiego: O osobie S. Sapińskiego nie można znaleźć informacji nawet w źródłach heraldycznych. Nie pełnił zapewne wysokich urzędów publicznych, nie zapisał się niczym ani w życiu politycznym ani w życiu kulturalnym Rzeczypospolitej. Jedynym źródłem informacji na jego temat jest inwentarz księgozbioru jaki posiadał (datowany na rok 1609) . $^{5}$. Sapiński zgromadził lub (przynajmniej w części) odziedziczył bibliotekę liczącą 81 książek. Obok literatury religijnej i pięknej dominowały tutaj książki o tematyce polityczno-prawnej - ok. 35\% całego księgozbioru. Piśmiennictwo polityczne reprezentowało 25 tytułów, co stanowiło $86 \%$ działu polityczno-prawnego biblioteki.

- Łukasza Opalińskiego marszałka nadwornego koronnego ${ }^{6}$. Ł. Opaliński (1612-1662) należal do elity politycznej i kulturalnej swoich czasów. Magnat koronny, jeden z najdoskonalej wykształconych ludzi epoki (odbył studia zagraniczne we Francji i Niderlandach), zapisał się w historii Rzeczypospolitej jako znakomity polityk i wybitny pisarz polityczny, moralista (autor m.in. Rozmowy Plebana $z$ Ziemianinem z 1641 roku, w której uzasadnial potrzebę przeprowadzenia reformy systemu parlamentarnego, satyry Coś nowego z 1650 roku stanowiącej ostrą krytykę życia umysłowego szlachty, życia dworskiego, stanu szkolnictwa polskiego itp. i apologii Polonia defensa...). Bogata biblioteka Ł. Opalińskiego liczyła ok. 500 tytułów książek. Dział literatury polityczno-prawnej stanowił ok. 54\% całego księgozbioru, natomiast ksiażki o tematyce politycznej obejmujące ok. 235 tytułów stanowily ok. $87 \%$ tegoż działu.

- Stanisława Lubienieckiego ${ }^{7}$ : S. Lubieniecki (1623-1675) był działaczem i pisarzem ariańskim (m.in. autorem Historia reformationis Polonicae, w której zawarł historię arianizmu przedstawionego na tle całego ruchu reformacyjnego). Obok historii, Lubieniecki zajmowal się także astronomią. Prace Lubienieckiego przyniosty mu dużą popularność wśród europejskich elit naukowych i kulturalnych. Od 1655 roku przebywał na emigracji w Hamburgu, rekonstruując tam swoją bibliotekę. Księgozbiór Lubienieckiego odtworzony za granicą liczył ok. 486 książek. Przeważały w nim dzieła z zakresu teologii. Dzzial literatury polityczno-prawnej stanowił natomiast ok. $35 \%$ całego księgozbioru. W obrębie tego działu można wyróżnić ok. 122 tytułów książek o tematyce politycznej (ok. 72\% całej literatury polityczno-prawnej).

- Henryka Szembeka ${ }^{8}$ : H. Szembek pełnił funkcję rajcy miasta Lwowa, jednak jak można przypuszczać pochodził ze znanego rodu szlacheckiego. Jedynym źródłem informacji na jego temat jest opublikowany przez Skoczka inwentarz księgozbioru pochodzący z 1651 roku. Biblioteka Szembeka była bardzo skromna. Obejmowała tylko 57 pozycji, wśród których wyróżniono dział książek polityczno- 
prawnych stanowiący ok. 35\% całego księgozbioru. Książki o tematyce politycznej w liczbie 12 tytułów stanowiły ok. $60 \%$ tego działu.

- Aleksandra Michała Lubomirskiego ${ }^{9}$ : A.M. Lubomirski (1614-1677) należał do grupy światłych magnatów polskich drugiej połowy XVII wieku. Odznaczał się wszechstronnym wykształceniem zdobytym m.in. na uczelniach niemieckich i niderlandzkich. Mimo dużej aktywności politycznej i wysokiego stanowiska wojewody krakowskiego, które piastował od 1668 roku, nie odegral znaczącej roli w życiu politycznym państwa, pozostając $w$ cieniu swego brata Jerzego. Swoją bibliotekę zgromadził na zamku w Wiśniczu. Należała ona do największych księgozbiorów jakie funkcjonowały na terenie Rzeczypospolitej w badanym okresie. Niestety w 1655 roku biblioteka uległa rozproszeniu i częściowemu zniszczeniu. Zrekonstruowany księgozbiór liczył według inwentarza z 1678 roku 329 pozycje. Obejmował dziela z zakresu nauk matematyczno-przyrodniczych, wojskowości, religii, sztuki itp. Dział literatury polityczno-prawnej stanowił ok. 33\% cakego księgozbioru, natomiast piśmiennictwo o tematyce politycznej obejmujące ok. 87 tytułów, stanowiło ok. 80\% tego działu.

- Macieja Grabskiego ${ }^{10}$ : M. Grabski podobnie jak Sapiński i Szembek nie odznaczył się niczym w historii kultury czy historii politycznej Rzeczypøspolitej. Nie osiągnął ani wysokich urzędów państwowych ani znacznego majątku. Był typowym przedstawicielem tzw. szlachty średniej. Zgromadził jednak dość znaczną bibliotekę, liczącą 142 książki. Wyodrębniony tutaj dział literatury polityczno-prawnej stanowił ok. $45 \%$ całego księgozbioru, natomiast książki o tematyce politycznej (55 tytułów) obejmowały $85 \%$ tego działu.

- Hieronima Pinocciego ${ }^{11}$ : Pinocci (1612-1672) pochodził z Włoch. W 1638 roku osiedlit się w Polsce, prowadząc tutaj działalność kupiecką. W 1649 roku został burmistrzem Krakowa, zaś w 1656 roku zarządcą mennicy we Lwowie. Od 1645 roku pełnił funkcję sekretarza królewskiego, kustosza i najwyższego pisarza Archiwum Królewskiego. Karierę Pinocciego uwieńczył indygenat otrzymany na sejmie 1662 roku. Był jednym z najwybitniejszych pisarzy ekonomicznych a także politycznych działających na terenie Polski w drugiej połowie XVII wieku. Dużą pomocą zarówno w służbie państwowej jak i w twórczości pisarskiej służyła mu cenna biblioteka licząca 1874 pozycje. Wśród wielu działów obecnych w tym księgozbiorze do największych należała grupa książek polityczno-prawnych (ok. $48 \%$ całego księgozbioru). Do pozycji politycznych zaliczono ok. 613 tytułów książek, co stanowilo ok. $68 \%$ działu polity czno-prawnego.

- Jana Sobieskiego ${ }^{12}$ : J. Sobieski (1629-1696), król polski od 1674 roku wywodził się ze świetnej rodziny magnackiej, w której żywe były tradycje służby obywatelskiej i przywiązanie do wartości kulturalnych. Otrzymał gruntowne wykształcenie kończąc Akademię Krakowską. Uzupełnieniem jego edukacji była podróż za granicę jaką odbył w latach 1646-1648. Sobieski już w młodości wybrał karierę wojskowa, której ukoronowaniem była buława hetmana wielkiego koronnego (1668 rok). Równocześnie nie zrezygnował $z$ aktywnego udziału $w$ życiu politycznym kraju, uczestnicząc począwszy od 1659 roku w pracach parlamentu Rzeczypospolitej. Biblioteka J. Sobieskiego liczyła około siedem tysięcy dzieł. Niniejsza praca oparta jest na jedynym zachowanym katalogu zbiorów opubliko- 
wanym przez J.T. Lubomirskiego. Katalog ów obejmuje tylko 1404 pozycje. Wyodrębniony dział literatury polityczno-prawnej stanowił ok. $41 \%$ tego zbioru. Do piśmiennictwa politycznego zakwalifikowano ok. 456 tytułów (ok. $80 \%$ calego zbioru polityczno-prawnego).

Analizę zawartości księgozbiorów wyżej wymienionych wlaścicieli oparto na opublikowanych inwentarzach tych bibliotek. Obok inwentarzy bibliotecznych wykorzystano źródła omawiające (w sposób bardzo pobieżny i wybiórczy) księgozbiory: podstarościego radomskiego Jana Strzembosza (ok. 1545-1606), humanisty i bibliofila wywodzącego się z zamożnej rodziny szlacheckiej (księgozbiór z końca XVI wieku) ${ }^{13}$; szlachcianki Justyny Lorkowskiej z 1615 roku $^{14}$; magnata wielkopolskiego, kasztelana nakielskiego Jana Grudzińskiego z 1624 roku $^{15}$; średnio zamożnego szlachcica Krzysztofa Dobińskiego łowczego gostyńskiego z połowy w. XVII-tego ${ }^{16}$; chorążego przemyskiego Krzysztofa Tomasza Drohojowskiego (zm. 1684), który wywodził się ze znanego rodu magnackiego ale nie osiągnął godności senatorskiej i nie przejawiał szczególnej aktywności politycznej ${ }^{17}$ (inwentarz jego księgozbioru datowany jest na 1676 rok); wojewody czernichowskiego Stanisława Kazimierza Bieniewskiego (zm. 1676) polityka, mówcy i działacza sejmowego, dyplomaty (był specjalistą od spraw kozackich), z którego bibliəteki znany jest księgozbiór podręczny wożony przez Bieniewskiego na sejmy 1659 i 1674 roku; wojewody wołyńskiego Jana Adama Stadnickiego (zm. 1713) (dwa spisy książek z 1693 i 1697 roku) i koniuszego wielkiego koronnego Jerzego Dzieduszyckiego (1670-1730) działacza i pisarza politycznego (inwentarz z lat 1694-1696) ${ }^{18}$ oraz szlachty krakowskiej z pierwszego trzydziestolecia XVIII wieku ${ }^{19}$.

Jako kryterium analizy zawartości wyróżnionych księgozbiorów szlacheckich przyjęto treść dzieł, które odnotowują badane inwentarze biblioteczne. Wyselekcjonowano w ten sposób wszystkie pozycje zwiazane z państwem, różnymi sferami jego działania (można tutaj wymienić m.in. sprawy wewnętrzne, zagraniczne, społeczne, wyznaniowe, ekonomiczne itp.) a także ze społeczeństwem obywatelskim obejmującym przede wszystkim stan szlachecki. Ponieważ w omawianych księgozbiorach występowały zarówno polonika jak i publikacje zagraniczne, druki piętnasto-, szesnasto- i siedemnastowieczne oraz książki drukowane i rękopiśmienne nie stosowano tutaj innych kryteriów doboru niż treść pozycji.

Podstawę rekonstrukcji oferty wydawniczej w zakresie literatury politycznej stanowily dane bibliograficzne ${ }^{20}$ oraz materiał statystyczny dotyczacy polskiego ruchu wydawniczego opublikowany przez M. Czarnowską ${ }^{21}$.

Podobnie jak w przypadku badań nad inwentarzami bibliotecznymi jako podstawowe kryterium selekcji danych stosowano treść publikacji ${ }^{22}$. Treść książki określono w pierwszej kolejności za pomocą analizy adnotacji treściowych zawartych w opisach pozycji bibliograficznych oraz w oparciu o zawartość treściową poszczególnych tytułów pozycji bibliograficznych, w przypadku braku adnotacji treściowych. Ten sposób postępowania pozwolił na wyodrębnienie zbioru publikacji o tematyce politycznej wydanych w latach 1501-1732. W tym przypadku, przyjęty zasięg chronologiczny pracy nie obowiązuje, gdyż w większości druki, które ukazały się przed 1587 rokiem, funkcjonowaly w obiegu czytelniczym badanego okresu. Data wydania druku ma znaczenie przede wszystkim w przypadku wydawnictw 
informacyjno-propagandowych, relacji oraz wydawnictw o charakterze prasowym. Jednak na podstawie analizy księgozbiorów szlacheckich można stwierdzić, że podobne publikacje tracąc z czasem na aktualności, pozostawały w obiegu czytelniczym, ze względu na swój walor przekazu historycznego.

Następne kryterium selekcji to założenie, według którego podczas analizy danych bibliograficznych uwzględniono tylko te tytuły co do których można sądzić, że funkcjonowały w krajowym obiegu czytelniczym. Zgodnie z tym założeniem zarejestrowano wszystkie dzieła autorów polskich (w tym także dzieła opublokowane za granica), publikacje autorów niepolskich ale zamieszkujących terytorium Rzeczypospolitej, uwzględniono także wszystkie pozycje wydane na terytorium Rzeczypospolitej.

Zbiór druków jaki powstał w oparciu o powyższe kryteria klasyrikacji jest w znacznym stopniu niepełny, gdyż nie obejmuje np. wydawnictw zagranicznych (niebędących polonikami) sprowadzanych do Polski. Ponadto w skutek niekompletności danych bibliograficznych zwłaszcza w zakresie wydawnictw o charakterze publicystycznym i informacyjno-propagandowym istnieje duże prawdopodobieństwo popełnienia błędu w ustaleniu prawdziwych proporcji między poszczególnymi grupami druków politycznych. Wreszcie opisy bibliograficzne pozbawione są często adnotacji treściowych co zwiększa niebezpieczeństwo błędnego rozszyfrowania i klasyfikacji wydawnictw.

Uwzględniając te zastrzeżenia przyjęto, że wybrana reprezentacja umożliwia statystykę ograniczoną do ujęć procentowych.

Ze względu na wielość zgromadzonych materiałów, w celu ich głębszej analizy, zmierzającej do wyodrębnienia podstawowych typów literatury politycznej, występujących w obiegu czytelniczym badanego okresu (innymi słowy w celu ustalenia kanonu lekturowego $w$ zakresie literatury politycznej) z uzyskanego zbioru druków wyróżniono publikacje, które miały co najmniej dwa wydania oraz wydawnictwa, których popularność potwierdzają źródła (np. herbarze wydawane zwykle w pojedyńczych edycjach).

Oczywiście, tak jak w czasach nam współczesnych nie można kategorycznie stwierdzić, że duża liczba wydań danej publikacji świadczy o popularności tegoż dzieła wśród czytelników. Ważnym problemem w tym przypadku jest zjawisko mecenatu szeroko rozpowszechnione w okresie staropolskim. Często zdarzało się tak, że mecenas zlecał druk danej publikacji niezależnie od stopnia zainteresowania nią publiczności czytelniczej. Jest to charakterystyczne zwłaszcza dla druków okolicznościowych i panegirycznych. W innym przypadku o wydaniu, nawet kilkakrotnym, książki decydowały koterie lub stronnictwa polityczne. Przykładem takiego wydawnictwa jest Cenzura kandidatorum Andrzej Olszowskiego publikowana w czasie elekcji 1669 roku w liczbie co najmniej dziesięciu wydań. Można przypuszczać, że przynajmniej kilka pierwszych wydań tego utworu, finansowanych było przez autora. W ocenie stopnia zainteresowania czytelnika określonym dziełem należy więc zwrócić uwagę na to, czy druk ów wydano nakładem drukarza, innymi słowy trzeba odpowiedzieć sobie na pytanie, czy z wydaniem druku wiąże się wyłącznie ryzyko drukarza. W przypadku gdy nakładem drukarza, a nie np. autora lub jego mecenasa czy zleceniodawcy ukazało się kilka edycji danej publikacji, można stwierdzić, że cieszyła się ona zainteresowaniem czytelników, gdyż jej 
wznowienia przynosiły drukarzowi lub wydawcy zyski finansowe. Jednak ze względu na złą kondycję materialną drukarstwa polskiego, oficyny krajowe rzadko podejmowały samodzielne inicjatywy mydawnicze. W zwiazku z tym własnym nakładem drukarza ukazywały się z reguły wydawnictwa takie jak kalendarze czy żywoty świętych, które wydawane w dużych nakładach przy małych kosztach jednostkowych gwarantowały duże zyski w odróżnieniu od np. wydawnictw naukowych.

Analiza danych bibliograficznych wskazuje na jeszcze jedną cechę produkcji wydawniczej badanego okresu - znaczna liczba poloników ukazała się w w oficynach zagranicznych. Dotyczy to przede wszystkim pozycji o dużej objętości (często wielotomowych) wymagających starannego opracowania typograficznego jak np. dzieła historyczne. Z formą druków tego rodzaju wiązał się dość długi czas realizacji mydania i odpowiednio wysoki koszt. Wydaje się, że krajowe oficyny wydawnicze nie były w stanie podołać podobnym wymaganiom dlatego publikacje i nowe edycje książek zlecano drukarzom zagranicznym.

Słaby rozwój drukarstwa polskiego determinował więc w pewnym stopniu kształt oferty wydawniczej. Obok czynników obiektywnych duży wpływ na repertuar wydawniczy miała cenzura państwowa i duchowna oraz autocenzura twórców.

Ingerencją cenzury objęte były wszystkie typy druków politycznych. O jej skuteczności świadczy np. analiza piśmiennictwa związanego z rokoszem Zebrzydowskich, w którym zdecydowaną przewage mialy druki regalistyczne nad publikacjami wyrażającymi racje rokoszan.

Mając na uwadze powyższe zastrzeżenia wydaje się, że przyjęte kryteria klasyfikacji pozwalają na częściowe odtworzenie repertuaru wydawniczego krajowych oficyn drukarskich w zakresie literatury politycznej i określenie względnie spójnych grup tematycznych występujących w wydawnictwach politycznych.

Repertuar wydawniczy obejmowat w badanym okresie przede wszystkim publikacje o tematyce: religijnej (dysputy religijne, piśmiennictwo dewocyjne i hagiograficzne, modlitewniki itp.), które stanowiły np. w 1740 roku ponad 40\% produkcji ${ }^{23}$; panegirycznej (obejmujące w latach duwdziestych XVII wieku ok. 22,7\% ogólnej liczby wydanych książek, w latach 1631-1640 wielkość ta wzrosła już do $39,6 \%$, utrzymując się do 1690 roku na preciętnym poziomie ok. 35\%, wzrastając w nasteppnych latach ${ }^{24}$; "gospodarskiej" (kalendarze i prognostyki, zielniki, podręczniki i poradniki gospodarowania itp.); oświatowo-naukowej (podręczniki szkolne, slowniki, gramatyki, lektury szkolne itp.).

Spośród wymienionych typów publikacji część zaliczono do piśmiennictwa politycznego np. niektóre utwory hagiograficzne i polemiczne, niewielką liczbę utworów panegirycznych adresowanych do osób znaczących w życiu społecznopolitycznym kraju (propagujących pewne idee polityczne, wzorce postępowania w działalności publicznej), poszczególne prognostyki i kalendarze zawierające treści polityczne oraz pozycje zwiazane ze sztuką wymowy.

Ogólna liczba wyróżnionych publikacji politycznych wynosiła ok. 4 tys. tytułów co stanowiło ok. 10\% wszystkich tytułów (ok. 39 tys.) wydanych w latach 1501-1732. W identyczny sposób kształtował się udział piśmiennictwa politycznego w ogólnej produkcji wydawniczej w obu połowach XVII-go stulecia. W przypadku poszczególnych dziesięcioleci ów udział kształtował się następująco: 
w latach 1501-1570 wynosit od ok. 4 (1551-1560) do ok. 10\% (1521-1530); wzrost nastąpił w latach 1571-1580 - ok. 16\% i w latach 1581-1590 - ok. 17\%; w latach 1591-1650 udzial tego typu wydawnictw wynosił od 8 do 10\% (wyjąwszy lata 1601-1610 - ok. $12 \%$ i lata 1631-1640 ok. 13\%); w latach 1651-1670 - ok. 14\%.

w latach 1671-1732 od ok. 5 (1721-1732) do ok. 10\% (1671-1680) przy czym wyjątkowym jest tutaj dziesięciolecie 1691-1700, w którym druki o tematyce politycznej stanowiły ok. 14\% ogólnej produkcji mydawniczej.

Wśród publikacji politycznych wydanych w latach 1501-1732 można wyróżnić następujące grupy druków: książki o tematyce historycznej (historia starożytna, Bizancjum, powszechna, dzieje krajów pozaeuropejskich, historia Rzeczypospolitej - zaliczone do literatury politycznej ze względu na poznawcze, ideologiczne, społeczno-polityczne, etyczne i dydaktyczne funkcje jakie wypełnia historia, będąca nauką o rozwoju życia społecznego, politycznego i struktur państwowo-prawnych);

książki z zakresu teorii państwa i wiążącą się z nimi publicystyką (w przypadku publicystyki wyróżniono trzy podstawowe grupy: utwory nawiązujące do zjawisk występujących w życiu społeczno-politycznym państwa, utwory zajmujące się relacjami kościół - państwo i kościół - stan szlachecki oraz zawierające polemiki wyznaniowe, utwory poświęcone sytuacji gospodarczej państwa); wszelkiego rodzaju publikacje o treści informacyjno-propagandowej oraz piśmiennictwo z zakresu sztuki wymowy.

Wymienione grupy tematyczne mają charakter umowny, nie stanowiąc rozłącznej i zamkniętej klasyfikacji. Trudności klasyfikacyjne wynikają z synkretyzmu problemowego dawnej literatury (np. publicystyka zawierała czessto elementy myślenia abstrakcyjnego i odwrotnie traktaty sensu stricto teoretyczne nie były pozbawione treści publicystycznych). W dalszej części niniejszej pracy przytoczono przykłady publikacji z owymi grupami bezpośrednio związanych, które uporządkowano na zasadzie chronologii przy czym decyduje tutaj data pierwszego wydania określonej publikacji danego autora.

Analizując zawartość badanych księgozbiorów szlacheckich można stwierdzić, że ich struktura tematyczna odpowiada w zasadzie przedstawionemu wyżej kanonowi piśmiennictwa omawianego typu.

\section{PUBLIKACJE HISTORYCZNE.}

Publikacje historyczne stanowią ok. 23\% wyodrębnionego zbioru druków, natomiast analiza poszczególnych inwentarzy księgozbiorów wskazuje na to, że zbiory o tej tematyce obejmowaly od ok. $33 \% \mathrm{w}$ bibliotece $\mathrm{H}$. Szembeka, do ok. $85 \%$ w bibliotekach S. Lubienieckiego i J. Sobieskiego ogółu publikacji politycznych.

\section{a) Historia starożytna}

Dorobek krajowych oficyn wydawniczych w zakresie historii antycznej był nieznaczny. Liczba publikacji wynosiła ok. 3\% ogółu druków politycznych.

Z historyków antycznego Rzymu wydano m.in. dzieła Cezara, Sallustiusza, Neposa, Liwiusza, Polibiusza, Pompejusza Trogusa w opracowaniu Justinusa, Wale- 
riusza Maximusa, Kurcjusza Rufusa, Tacyta, Swetoniusza, a z greckojęzycznych historyków rzymskich: Józefa Flawiusza, Plutarcha, Dionizjusza z Halikarnasu i Dionizjusza Afra. Ograniczenie się w tym przypadku tylko do zestawienia nazwisk może być mylące bowiem dzieła wymienionych autorów ukazywały się często w wyborach np. Vitae parallelae Plutarcha lub drukowano prace mniej istotne np. wydano De vita lulii Agricolae... Tacyta w dwóch edycjach z 1632 i 1643 r., pomijając Annales...

Wśród wymienionych autorów największą popularnością cieszył się Józef Flawiusz, którego Wojna żydowska doczekała się sześciu wydań w latach 15881725 (w całości), natomiast drugi tom dzieła ukazał się w Chronografii... Anzelma Polaka, wydanej w ośmiu edycjach w latach 1595-1725.

Dzieła z zakresu historii starożytnej Grecji stanowiły zaledwie margines w krajowym repertuarze wydawniczym. Można tutaj wskazać na brak krajowych edycji dzieł takich historyków jak Herodot, Ksenofont czy Tukidydes. Opisy bibliograficzne wskazują natomiast na dużą liczbę cytowań $z$ ich twórczości. $Z$ punktu widzenia liczby wydań, największą popularnością cieszyły się dzieje Aleksandra Wielkiego, zawarte w Aleksandrze Wielkim i Cezarze Plutarcha, dziele współwydanym z tłumaczeniem Kurcjusza Rufusa O dziejach Aleksandra Wielkiego w 1614 i 1618 roku. Ponadto należy wspomnieć o powieści Historia o żywocie ... króla macedońskiego, która miała dziewięć wydań począwszy od 1550 roku i licznych dialogach szkolnych poświęconych tej postaci.

Opracowania nowożytnych historyków dziejów antycznych tworzyły nieliczną grupę w wyróżnionym zbiorze wydawnictw. Produkcja krajowych oficyn drukarskich nie odzwierciedlała dorobku europejskiego $w$ tej dziedzinie. Zabrakło polskich edycji prac takich pisarzy jak m.in. Joseph Juste Scaliger, Julius Caesar Scaliger, Barnabé Brisson, Carlo Sigonio, Isaac Casaubon, lacobus Cuiacius czołowych historyków okresu Renesansu, czy autorów siedemnastowiecznych m.in. Eryciusa Puteanusa, Ioannesa G.Vossiusa lub loannesa Althusiusa.

Wśród poloników jakie ukazały się w latach 1501-1732 można wymienić m.in.: żywoty Antonio Guevary Horologium principis seu de vita M.Aurelii imp. wydane w 1615 i 1636 roku; De conditore Imperii Romani primo rege Romulo Jana Raue z 1648 r. czy De senatu... Romano Jana Zamoyskiego, trzy wydania zagraniczne w latach 1563-1670; słowniki starożytności np. Parnassus illustratus..., cztery wydania z lat 1712-1730 oraz traktaty polityczne: Princeps ex Cornelio Tacito z 1636 (Leyda) i 1645 (Gdańsk) roku Abrahama Goelnitza, Instituto politica C.Cornelii Taciti verbis Pawla Iwanickiego, sześć wydań zagranicznych w latach 1641-1728 i Politica de arcanis regnorum... ex Tacito... Lentulusa Cyriacusa z Elblaga, trzy wydania w latach 1655-1666 (w XVII w. wzrasta popularność dziet Tacyta, które traktowano jako podręczniki mądrości politycznej i sztuki rządzenia) ${ }^{25}$.

Znacznie rzadziej występują w danych bibliograficznych nowożytne opracowania dziejów antycznej Grecji.

Analiza dostępnych inwentarzy bibliotek szlacheckich wskazuje na to, że publikacje dotyczace historii starożytnej obejmowały od 7\% (biblioteka A.M. Lubomirskiego) do 55\% (biblioteka S. Lubienieckiego) ogólnej liczby dzieł politycznych. Szczególnie bogate były działy historii starożytnej w zbiorach: S. Lubienieckiego, Ł. Opalińskiego, H. Pinocciego i J. Sobieskiego. Pod względem jakościowym i 
ilościowym ważne pozycje znajdowały się także w bibliotekach: Lubomirskiego a także jak można przypuszczać J. Strzembosza, S.K. Bieniewskiego, K.T. Drohojowskiego, J. Dzieduszyckiego czy J.A. Stadnickiego.

Księgozbiory S. Sapińskiego, J. Lorkowskiej i M. Grabskiego zawierały jedynie kilka tytułów z omawianej dziedziny.

Do najczęściej spotykanych historyków rzymskich należał Tacyt, którego dzieła - zwłaszcza Annales - znajdowały się w siedmiu inwentarzach, w sześciu inwentarzach występowalo Factorum et dictorum memorabilium Waleriusza Maximusa (utwór o charakterze retorycznym, wielokrotnie cytowany w krajowych publikacjach i wydany w przekładzie Andrzeja Wargockigo w 1609 roku), w pięciu inwentarzach zarejestrowano Annales Tytusa Liwiusza (krajowe edycje dzieł Liwiusza to: Dwa bunty szkodliwe z 1598 roku i Fasti Romanorum Liviani z 1676 roku), także w pięciu inwentarzach można odnotować Vitae Swetoniusza (istniała tylko jedna krajowa edycja wydana w 1524 roku pt. Liber Cesareum illustrium virorum), Wojna żydowska Józefa Flawiusza znalazła się w trzech bibliotekach.

W porównaniu z historią Rzymu, dzieje antycznej Grecji reprezentowane były w badanych księgozbiorach dosyć nielicznie. Wymienić tu można Historiae Herodota oraz Bibliothecae historiae Diodora Sycylijskiego, rejestrowane w zbiorach: S. Lubienieckiego, Ł. Opalińskiego, H. Pinocciego i J. Sobieskiego.

W inwentarzu biblioteki S. Sapińskiego odnotowano m.in. Historie o Aleksandrze królu macedońskim, w księgozbiorze J. Lorkowskiej jedno z dzieł Sallustiusza (być może De coniuratione Cattilinae lub Bellum lugurtinum wydane trzykrotnie w latach 1511-1517), w bibliotece M. Grabskiego De vita Iulii Agricolae Tacyta.

Nowożytne opracowania poświęcone historii starożytnej znalazły się m.in. w bibliotekach S. Lubienieckiego, Ł. Opalińskiego, H. Pinocciego i J. Sobieskiego, tworząc liczną grupę publikacji. Kilka prac o podobnej tematyce posiadał także A.M. Lubomirski.

Wśród publikacji tego typu można wymienić np. Historiarum... C. Sigonio (księgozbiory $Ł$. Opalińskiego i J. Sobieskiego), De formulis solemnibus populi Romani B. Brissona (księgozbiory S. Lubienieckiego i H. Pinocciego) a z dziet autorów siedemnastowiecznych De historicis latinis J.G. Vossiusa (księgozbiory S. Lubienieckiego i Ł. Opalińskiego) lub Roma sotterranea Antonio Bosio (księgozbiory . Opalińskiego i A.M. Lubomirskiego).

\section{b) Historia Bizancjum}

Publikacje krajowe z zakresu dziejów Bizancjum były nieliczne. Brak było podstawowych dziet takich autorów jak: Propkop z Cezarei, Theofanes, Konstantyn Porfireogenet, czy dzieł zbiorowych np. Corpus historiae Bisantinae.

Ukazało się natomiast kilka prac o charakterze biograficznym np. Theodosius Magnus ex variis autoribus Joachima Pastoriusa z 1664 r. Jednym ze źródeł wiedzy historycznej na ten temat, mogły być także publikacje zajmujące się dziejami kościoła np. Roczne dzieje kościelne... Caesara Baroniusa, wydane w trzøch edycjach w latach 1603-1703 czy Historia Schizrny Greckiej anonimowe wydawnictwo z 1698 roku. 
Książki z tej dziedziny znalazły się w kilku księgozbiorach: Ł. Opalińskiego, $H$. Pinocciego i J. Sobieskiego.

\section{c) Historia powszechna}

Wydawnictwa z zakresu historii powszechnej (nowożytnej) stanowiły ok. 1,6\% calej produkcji publikacji politycznych w latach 1501-1732, natomiast ich udział w badanych bibliotekach kształtował się w granicach od 4\% (księgozbiory Ł. Opalińskiego i J. Sobieskiego) do 12\% (księgozbiory S. Lubienieckiego i H. Pinocciego). W przypadku bibliotek S. Sapińskiego, J. Lorkowskiej, H. Szembeka i M. Grabskiego, tylko w księgozbiorze tego ostatniego można znaleźć dzieła o tej tematyce (Descripto orbis Lucasa Lindy oraz niezidentyfikowane Flosculi historiarum... sive historia universalis...).

Największą liczbę edycji osiągnęły dzieła: Marcina Bielskiego Kronika wszystkiego świata, wydana trzykrotnie w latach 1551-1564; Giovanniego Botero Relatie powszechne, wydane trzykrotnie w latach 1609-1659; L. Linda Descripto Orbis... i Orbis lumen..., osiem edycji zagranicznych z lat 1620-1672; dziela polihistora Jana Jonstona - Historiae universalis civilis..., osiem wydań zagranicznych z lat 16331690 i Polyhistor, trzy wydania z lat 1660-1667 - które służyły jako podręczniki w polskich szkołach protestanckich; loannesa Laetusa Compedium historiae universalis, trzy wydania zagarniczne w latach 1643-1661 oraz Pawła Piaseckiego Chronica gestorum in Europa singularum, trzy wydania krajowe $z$ lat 1645-1648 i jedno zagraniczne z 1649 roku (praca Piaseckiego jest przykladem licznych dziet, w których dominują dzieje Rzeczypospolitej w powiązaniu z obcymi, zwłaszcza ościennymi państwami) i Jana Drewsa Flos regnorum..., trzy edycje z lat 1706-1732.

$W$ dostępnych księgozbiorach szlacheckich obok autorów rodzimych ( $M$. Bielski, J. Jonston, P. Piasecki czy gdańszczanin Philippus Cluverius) występowali najwybitniejsi historycy europejscy szesnasto-i siedemnastowieczni. Należeli do nich m.in. Paolo Giovio (jego Historiarum sui temporis... znalazlo sie w bibliotekach S. Lubienieckiego, Ł. Opalińskiego, H. Pinocciego i J. Sobieskiego), Johannes Sleidanus autor De quartuor summis imperiis, które rejestrowały biblioteki $H$. Pinocciego i S.K. Bieniewskiego oraz Jacques Auguste Thou, którego Historiarum suitemporis... było w posiadaniu Ł. Opalińskiego, S. Lubienieckiego, J. Sobieskiego i Zasławskiego. Można wspomnieć także o /l mercurio overo historia dei correnti tempi 1635-1655 Vittorio Siri (biblioteki H. Pinocciego i A.M. Lubomirskiego). Chociaż wymienione opracowanie nie miały polskich edycji, w kraju ukazały się wydawnictwa poświęcone ich autorom np. Jan Piotr Titz wydał monografię J.A. Thou pt. Viri illustri lacobi Augusti Thuani voluminum histơricum recensio.

\section{d) Historia krajów pozaeuropejskich i europejskich}

O ile publikacje z zakresu dziejów powszechnych - w tym historii tzw. Nowego Świata - miały zauważalny udział w repertuarze wydawniczym krajowych oficyn drukarskich, o tyle dzieła zajmujące się wyłącznie historią krajów pozaeuropejskich reprezentowane są w danych bibliograficznych zaledwie kilkunastoma tytułami. 
Zwykle są to pozycje o charakterze hagiograficznym, diariusze i sprawozdania z działalności misjonarskiej, w których czytelnik mógł znaleźć w sposób pośredni informacje o narodach, kulturach, państwach innych niż europejskie. Przykładami takich publikacji są dzieła: Jacobusa Torresa O rozszerzeniu wiary ... w Ameryce... z 1603 roku i Kaspra Drużbickiego Vita et mors...Alberti Męciński z 1661 roku. Z prac sensu stricto historycznych lub historyczno-geograficznych można wymienić np. dzieła gdańskiego uczonego Gerharda Arthusa: Historische beschreibung des Königreich Guinea z 1603 roku i Historiae Indiae orientalis... z 1608 roku (oba tytuły ukazały się za granica).

Stosunkowo największy zbiór publikacji o tej tematyce posiadał A.M. Lubomirski. Stanowiły one ok. 8\% ogółu książek o tematyce politycznej znajdujących się w jego bibliotece a w księgozbiorach $七$. Opalińskiego, H. Pinocciego i J. Sobieskiego nie więcej niż $2 \%$. Można wymienić tutaj m.in. Novus orbis... I.Laetusa (biblioteki Ł. Opalińskiego i A.M. Lubomirskiego), Histoire de la cour du roy de la Chine Michela Baudiera (biblioteka J. Sobieskiego) czy Istoria naturale e morale delle Indie (biblioteka H. Pinocciego) Emanuela Acosty.

Grupa wydawnictw zajmujących się historią państw europejskich obejmuje ok. $3 \%$ poloników politycznych, z czego $26 \%$ to publikacje poświęcone Turcji (razem $z$ historią Persji i chanatów tatarskich ok. 30\%), 10\% wydawnictwa dotyczące Moskwy, 7\% dotyczące historii Francji, 5\% poświęcone kolejno historii: Szwecji, Czech, Niemiec i Węgier, 3\% dotyczące Wenecji. Wśród publikacji tego typu większość stanowily drobñe wydawnictwa z zakresu historii politycznej czasów współczesnych (opisy wojen, bitew, opisy konkretnych wydarzeń politycznych, diariusze podróży itp.) i druki o charakterze biograficznym (można tutaj wspomnieć $\mathrm{m}$.in. o dialogach teatralıych, w których żywoty monarchów europejskich stanowiły często osnowę dramatu). Ujęcia całościowe dominowały w piśmiennictwie poświęconym sąsiadom Rzeczypospolitej.

Udział omawianych wydawnictw w księgozbiorach szlacheckich ksztaltował się w granicach od ok. 18\% (księgozbiór S. Lubienieckiego) do ok. $41 \%$ w bibliotece J. Sobieskiego.

Stosunkowo dużo (pięć) publikacji posiadał S. Sapiński, natomiast księgozbiór M. Grabskiego zawierał tylko jedną pozycję.

Obok danych procentowych dotyczących produkcji druków w zakresie dziejów państw europejskich, pewne preferencje wydawnicze potwierdza także zestawienie tytułów dzieł, które uzyskały wielokrotne wydania np. Chronologia o wywodzie narodu cesarzów tureckich... Wawrzyńca Chlebowskiego, pięć edycji z lat 16091620; Przeważna legacja... Krzysztofa Zbaraskiego... Samuela Twardowskiego, trzy edycje $z$ lat 1633-1706; Dwór cesarza i residencja jego $w$ Konstantynopolu Szymona Starowolskiego, siedem edycji z lat 1646-1715; historię Niemiec reprezentuje tutaj m.in. Erhard Wassenberg autor Florus Germanicus... wydanego w trzech edycjach zagranicznych w latach 1641-1648 i trzech edycjach krajowych w latach 1642-1662; dzieje Francji ujmują publikacje Petrusa Mathaeusa Minister status seu considerationes politicae super vita Nicolai Neovilli Villa Regi (dzıeło to, ukazalo się w tłumaczeniu polskim w 1640 roku i w wersji łacińskiej wydanej przez Joachima Pastoriusa w 1658 i 1664 roku) i Stephanusa Petiota Panegyricis Ludovico XIII... triumphatori, wydany siedmiokrotnie w latach 1680-1731. 
W księgozbiorach $S$. Lubienieckiego, Ł. Opalińskiego, H. Pinocciego, A.M. Lubomirskiego i J. Sobieskiego znalazły się dzieła o charakterze ujęć całościowych, począwszy od dziejów najdawniejszych po czasy współczesne poszczególnych państw, tytuły poświęcone europejskim konfliktom zbrojnym, biografie, pamiętniki, diariusze oraz publikacje o tematyce genealogicznej i heraldycznej. We wszystkich wyżej wymienionych księgozbiorach występują głównie pozycje dotyczące dziejów Francji, Niderlandów i Włoch (według W. Jabłońskiej podobna tematyka dominuje także w bibliotece J. Dzieduszyckiego). ${ }^{26}$

Wśród naj̣częściej spotykanych dzieł należy wymienić: La historia d'ltalia Francesco Guicciardiniego (księgozbiory J. Strzembosza, Ł. Opalińskiego, H. Pinocciego i J. Sobieskiego), Rerum Scoticarum Historia Georga Buchanana (księgozbiory S. Lubienieckiego, Ł. Opalińskiego i J. Sobieskiego). Spośród siedemnastowiecznych dziejopisów niewątpliwie największą popularnością cieszył się historyk powstania Niderlandów przeciwko panowaniu hiszpańskiemu, reprezentujący punkt widzenia Habsburgów - Famianus Strada, autor De bello Belgico (biblioteki S. Lubienieckiego, Ł. Opalińskiego, H. Pinocciego, A.M. Lubomirskiego, J. Sobieskiego). Historii Niderlandów poświęcone było także dzieło Hugo Grotiusa De antiquitate Reipublicae Batavicae, które znalazło się w księgozbiorach Ł. Opalińskiego i A.M. Lubomirskiego (wyżej wymienione prace nie miały krajowych edycji).

$Z$ kilku tytulów odnotowanych $w$ inwentarzu biblioteki S. Sapińskiego można wymienić np. zarys geograficzno-historyczny Marcina Broniowskiego Tartariae descripto i niezidentyfikowane dzieło o tytule Rerum Moscoviticarum commentarii, M. Grabski posiadał w swoich zbiorach jedynie niezidentyfikowaną historię Wenecji (według P. Buchwald-Pelcowej mogia to być Wenecja Krzysztofa Warszewickiego). ${ }^{27}$

\section{e) Historia Rzeczypospolitej}

Dzieła o tej tematyce stanowią ok. 15\% zbioru poloników politycznych. Jest to obok publicystyki i druków informacyjno-propagandowych największy dzial publikacji omawianego typu.

W badanych księgozbiorach ów dział liczył od kilku do kilkudziesięciu tytułów. Wartości procentowe kształtowały się od 5\% (biblioteka Ł. Opalińskiego) do 16\% (biblioteka A.M. Lubomirskiego).

W zbiorze S. Sapińskiego były dwie książki z tego zakresu, co stanowiło już $8 \%$ wszystkich publikacji politycznych tej biblioteki, natomiast księgozbiór M. Grabskiego zawierał dwanaście tytułów, czyli ok. $22 \%$.

\section{e.1) Całościowe opracowania dziejów Rzeczypospolitej i publikacje historyczne zajmujące się poszczególnymi okresami $w$ historii kraju.}

Opracowania tego typu stanowią ok. $5 \%$ wszystkich druków politycznych, przy czym większcść $z$ nich to wydawnictwa pochodzące $z$ XVI i przełomu wieków oraz ich siedemnastowieczne wzncwienia. 
Skalę popularności tego rodzaju prac historycznych jak ujęcia całościowe, obrazuje duża ilość tytułów, które miały liczne wznowienia. Z dzieł szesnastowiecznych należy wymienić: Chronica polonorum M. Miechowity, wydaną dwukrotnie w latach 1519 [wydanie nierozprowadzane] -1521; De origine et gestis Polonorum, trzy wydania zagraniczne w latach 1555-1568 i Polonia, cztery wydania zagraniczne w latach 1575-1589 Marcina Kromera; Chronicon Jana Herburta wydany w pięciu edycjach zagranicznych z lat 1571-1658 i dwóch krajowych z lat 1609-1647; Sarmatiae Europeae descripto (z 1573 roku Macieja Stryjkowskiego) Aleksandra Gwagina, osiem edycji w tym trzy krajowe z lat 1578-1642; Annales Stanisława Sarnickiego, pięć wydań krajowych w latach 1582-1685. W końcu, należy przypomnieć niepełne wydanie Historii Jana Dlugosza, które ukazało się w dwóch edycjach krajowych $z$ lat 1614-1615 $\mathrm{i}$ jednej zagranicznej z lat 1711-1712.

Wymienione publikacje charakteryzują się tym, że nie ograniczając się zwykle do opisu wydarzeń history cznych, dażyły do określenia ich przyczyn i skutków. Stąd w dziełach M. Miechowity, M. Kromera, J. Herburta i J. Długosza występowaly elementy krytycznej oceny różnych negatywnych zjawisk zachodzących w życiu społeczno-politycznym kraju, przy równoczesnej aprobacie ogólnych założeń ustrojowych państwa. Apologetyczne ujęcie dziejów ojczystych dominuje natomiast w pracach M. Stryjkowskiego, S. Sarnickiego.

W XVII wieku miejsce głębokich syntez historycznych zajęty publikacje w większości o charakterze kompilacyjnym, podręcznikowym np. Respublica sive status Regni Poloniae wydana czterokrotnie w latach 1626-1642 przez oficynę Elzewirów; Polonia zarys historyczno-geograficzny Szymona Starowolskiego (dwie edycje zagraniczne i dwie krajowe z lat 1632-1669); Florus Polonicus J.Pastoriusa, sześć edycji w tym trzy zagraniczne z lat 1641-1679 oraz pierwsza część dzieła Jana Krzysztofa Hartknocha De Respublica Polonica wydanego w trzech zagranicznych edycjach w latach 1678-1698.

Dużą ilością edycji cieszyły się także dzieła określone tutaj jako ujęcia poszczególnych fragmentów dziejów Rzeczypospolitej, i tak: Annales Stanislawa Orzechowskiego miało dwa wydania krajowe w 1611 roku i w 1643 oraz jedną edycję zagraniczną z 1712 roku; Gestorum... Vladislai... Erharda Wasssenberga wydano w trzech edycjach w latach 1641-1649; Gestorum populi Poloni... liber II Andrzeja Maksymiliana Fredry ukazało się w trzech wydaniach krajowych w latach 16521660 i jednym zagranicznym z 1698 roku; Annalium Poloniae... Wespazjana Kochowskiego wydano trzykrotnie w latach 1683-1698; Singularia quaedam Polonica... Mikołaja Chwałkowskiego wydano czterokrotnie w latach 1686-1698.

Wśród wymienionych publikacji większość stanowiły dzieła z zakresu historii politycznej czasów współczesnych, pełne subiektywnych ocen i treści publicystycznych.

W zbadanych inwentarzach bibliotecznych znalazly się wszystkie dzieła wymienione powyżej oraz takie publikacje jak: De rebus gestis...Sigismundi III Andreja Lipskiego, Dzieje w Koronie Polskiej Łukasza Górnickiego, Opera posthuma historica... Stanisława Łubieńskiego, Polonia Stanisława Krzysztanowicza i in.

Spośród prac o charakterze ujęć całościowych najczęściej inwentarze bibliotek odnotowują dzieła M. Kromera, obecne w dwunastu księgozbiorach. W bibliotekach 
H. Pinocciego (rękopis), A.M. Lubomirskiego (rękopis), J.A. Stadnickiego i J. Sobieskiego znalazła się Historia J. Długosza (obłożona edyktem Zygmunta III zabraniającym publikowania i rozpowszechniania wydrukowanych już egzemplarzy edycji z 1615 roku). Posiadaczem tego dzieła był także niezidentyfikowany szlachcic wielkopolski (według inwentarza bibliotecznego z 1651 roku).

Po 1709 roku największą popularność zdobyło dzieło Andrzeja Chryzostoma Załuskiego Epistoloae - dosyć chaotyczny zbiór dokumentów życia politycznego obejmujący okres od śmierci Marii Ludwiki po pierwsze dziesięciolecie XVIII wieku - o czym świadczy zawartość inwentarzy szlachty krakowskiej omawianych przez H. Bogdanow. Dzieło Załuskiego prezentuje dzieje poszczególnych okresów Rzeczypospolitej. Ponadto można wspomnieć m.in. o opracowanaich Jana Dymitra Solikowskiego Commentarius....rerum Polonicarum a morte Sigismundi Augusti (księgozbiory H. Pinocciego, A.M. Lubomirskiego i J. Sobieskiego) i A.M. Fredry Gestorum... (księgozbiór A.M. Lubomirskiego).

W dużych bibliotekach ( . Opalińskiego, H. Pinocciego itp.) znajdowały się też dzieła autorów obcych, niedrukowane na terenie Rzeczypospolitej np. Polonicae historiae corpus loannesa Pistoriusa z Hessen (księgozbiór J. Sobieskiego).

\section{e.2) Historia wojen prowadzonych przez Rzeczpospolitą}

Udział publikacji tego typu w zbiorze wydawnictw politycznych wynosił ok. $3 \%$. Zawierały one historyczne zarysy genezy i przebiegu konfliktów zbrojnych, w których uczestniczyły wojska Rzeczypospolitej. Są to m.in. De bello Moscovitico... Reinholda Heidensteina, jedno wydanie krajowe z 1584 roku i cztery zagraniczne z lat 1588-1600; Wojna Kozacka i Wojna domowa z Kozaki S. Twardowskiego, dziela wydane w trzech edycjach w latach 1651-1681; Bellum Scythio Cosacium J. Pastoriusa, praca wydana trzykrotnie w latach 1652-1665 (nowa - rozszerzona i uzupełniona - wersja ukazała się pt. Historiae Poloniae... w trzech edycjach z lat 1680-1685); Nowa Gigantomachia Augustyna Kordeckiego, drukowana trzykrotnie do 1717 roku, której przeróbka pióra Stanisława Kobierzyckiego została opublikowana w 1659 roku pt. Obsidio Clari Montsi Częstochowiensis...

Cechą charakterystyczną wymienionych wydawnictw było to, że opisywały wydarzenia z najbliższej perspektywy historycznej, nie unikając treści publicystycznych a nawet propagandowych.

Związek refleksji historycznej z warstwą aktualną utworów uwidocznił się zwłaszcza w piśmiennictwie poświęconym powstaniu Chmielnickiego, okresowi Potopu - wydarzeniom, które zagroziły samodzielnemu bytowi państwowemu Rzeczypospolitej.

W tym kontekście wydaje się zrozumiałe, że właśnie dzieje wojen kozackich i szwedzkich, nie zapominając o dużym zespole opracowań dotyczących konfliktów z Turcją, znalazły najpełniejsze odzwierciedlenie w histografii polskiej XVII wieku. Dlatego też, w większości księgozbiorów szlacheckich powstałych po 1660 roku występowały książki o tej tematyce, przy czym obok wspomnianych pisarzy warto także wymienić Wojciecha Kojałowicza autora De rebus anno 1648-1649 contra 
Zaporoviensis oraz $Ł$. Opalińskiego Historia... wojny szwedzkiej (autorstwo tego dziela przypisuje się także Janowi Stefanowi Wydżdze).

Oczywiście w omawianych ksiegozbiorach nie zabrakło także publikacji dotyczących konfliktów z Moskwąnp. inwentarz bibliotekiS. Sapińskiego odnotowuje utwór Jana Żabczyca Mars moskiewski krwawy i z Turcją m.in. Commentariorum Chotinenesis... Jakuba Sobieskiego (biblioteki Ł. Opalińskiego, M. Grabskiego i J. Dzieduszyckiego).

\section{e.3) Biografistyka, genealogia - heraldyka}

Dział publikacji z tego zakresu przeważa wśród wydawnictw histograficznych poświęconych dziejom Rzeczypospolitej. Stanowi on ok. 7\% ogółu wyodrębnionych publikacji politycznych.

Istotą piśmiennictwa tego typu było to, że w przystępnej formie popularyzowało ono historię kraju wśród najszerszych kręgów czytelników, co wpływało w znaczący sposób na decyzje wydawnicze rodzimych oficyn wydawniczych.

Spośród dzieł o charakterze biograficznym można wymienić m.in.: Vitae regum Polonorum Klemensa Janickiego, wydane w czternastu edycjach w latach 15651670; Pamiętnik królów i książąt polskich Sebastiana Klonowica, wydany sześciokrotnie w latach 1576-1697; Vita...Stephani Regis Krzysztofa Warszewickiego, wznowione czterokrotnie w latach 1587-1627 (edycje krajowe) i dwukrotnie w latach 1588-1627 (edycje zagraniczne); Thron ojczysty... Augustyna Kołudzkiego, wydany w trzech edycjach $z$ lat 1707-1727.

W tym miejscu nie można pominąć wydawnictw hagiograficznych, zawierających niekiedy wątki polityczne, zwłaszcza w kontekście relacji państwo-Kościół katolicki (szczególną rolę odgrywał tu kult św. Stanislawa).

Przykładem takich dzieł są Żywoty świętych... Piotra Skargi, wydane w piętnastu edycjach w latach 1579-1700 i lcones... Marcina Baroniusza, sześć wydań w latach 1602-1609.

Silą rzeczy treści biograficzne występowały także w utworach parenetycznych takich jak np. Reges, sancti, bellatores...Poloni K. Warszewickiego, jedno wydanie zagraniczne z 1601 roku i jedno krajowe z 1629; Wizerunek wiecznej sławy Sauromatów starych (pod kolejnymi edycjami tego utworu podpisywali się Wawrzyniec Chlebowski, Paweł Palczowski i Sebastian Aleksander Zakrzewski), który miał co najmniej siedem edycji w latach 1613-1645.

Powyższe publikacje niosły często określone przesłanie ideologiczne i polityczne (dominował tu nurt konserwatywny).

W przeciwieństwie do omówionych powyżej książek, herbarze wydawano zwykle w pojedyńczych edycjach np. Panoszę z 1575 roku, Gniazdo cnoty z 1578 oraz Herby rycerstwa polskiego z 1584 - dzieła Bartosza Paprockiego; Poczet mężnego rycerstwa polskiego z 1634 roku, Jana Karola Dachnowskiego; Herbarz szlachty litewskiejz 1653, W. Kojałowicza; Poczet herbów szlachty Korony Polskiej... Wadawa Potockiego z 1696; Herby polskie... Antoniego Swacha, dwa wydania z 1705 roku.

Herbarze byly tylko jednym z rodzajów wydawnictw zawierających informacje o charakterze genealogicznym. Inne publikacje to m.in. panegiryki, epitafia, kazania 
okolicznościowe itp. Ponadto, podobne treści można było znaleźć właściwie w każdym dziele historycznym.

Analizując dostępne inwentarze księgozbiorów szlacheckich można stwierdzić, że przeważająca ich część rejestruje druki omawianych typów. Ich liczba waha się od kilku do kilkunastu tytułów (przeważają utwory biograficzne).

Wśród nich można wymienić: Compendium chronicorum Poloniae secundum seriem et succesiones omnium principium Aleksandra Gwagina (biblioteka $\mathrm{H}$. Szembeka), Ines Lechias... Alberta Ines (biblioteki A.M. Lubomirskiego i J. Sobieskiego) czy Icones książąt i królów polskich Jana Gołuchowskiego (księgozbiór H. Pinocciego).

Wydawnictwa heraldyczne reprezentują: Herbarz polski Marcina z Urzędowa (księgozbiór J. Sobieskiego) i Orbis Polonus Szymona Okolskiego (biblioteki $Ł$. Opalińskiego i J.A. Stadnickiego).

\section{PUBLIKACJE Z ZAKRESU TEORII PANSTWA I SPOŁECZEŃSTWA ORAZ PUBLICYSTYKA}

Wśród ogółu publikacji politycznych piśmiennictwo tego rodzaju obejmowało ok. $43 \%$ przy czym $30 \%$ to publicystyka. $W$ badanych ksiegozbiorach podobna literatura stanowiła od 9\% (biblioteka S. Lubienieckiego) do ok. 23\% (biblioteka $Ł$. Opalińskiego). W tej grupie zdecydowanie przeważają traktaty polityczne (największy zbiór wydawnictw publicystycznych posiadał H. Pinocci - ok. 25 tytułów, co stanowiło niewiele ponad $4 \%$ ogółu publikacji politycznych rejestrowanych $w$ tej bibliotece).

W bibliotece S. Sapińskiego wielkości te wynosiły ok. 40\%, w tym publicystyki $24 \%$, M. Grabskiego ok. $36 \%$, w tym $16 \%$ publicystyki.

\section{a) Publikacje z zakresu teorii państwa i społeczeństwa.}

Dziela z tej dziedziny stanowity ok. 13\% druków politycznych, które ukazały się w latach 1501-1732.

Przyjmuje się, że podstawą teoretycznej wiedzy o państwie, polityce, prawie a także społeczeństwie, był w badanym okresie dorobek intelektuainy pisarzy starożytnych. Dział publikacji tego rodzaju stanowił w wyróżnionym zbiorze druków ok. $1,6 \%$ i obejmował zarówno piśmiennictwo wydawane w wersji oryginalnej jak i tzw. „przeróbki” o zaktualizowanej treści.

Znaczenie literatury starożytnej wynikało m.in. $z$ tego, że program nauczania polityki i prawa obowiązujący w szkolnictwie polskim (zwłaszcza w katolickim) oparty był o dzieła m.in. Arystotelesa, Cycerona, Platona.

Szczególny wpływ na ksztalt polskiej myśli politycznej wywarły prace Arystotelesa. Jego krajowe edycje to np. Aristoteles politicorum... w opracowaniu C. Sigoniusa wydane w latach 1557-1577, thumaczone przez Sebastiana Petrycego i opublikowane pt. Politika Aristotelesowe w 1605 roku oraz tegoż thumacza Etyka Aristotelesowa z 1618 roku. Etyce poświęcił swoje opracowania Jan Crell (wydana w dwóch edycjach Etica Aristotelica i Prima ethices elementa z 1635 roku). Prace 
Crella są istotne z tego względu, że chociaż śladem swoich poprzedników rozpatrywał kwestie społeczno-polityczne w kategoriach moralnych, przedmiotem jego zainteresowania była już nowożytna problematyka np. prawo narodów czy prawo naturalne.

Należy także wspomnieć o dziełach Jakuba Piotrowickiego: Quaestio de principis et natura z 1623 i Quaestio de optima Reipublica forma ab Aristotele definita z 1626 roku.

Zważywszy na rolę jaką odgrywał platonizm w kształtowaniu się nauki o państwie zwraca uwagę fakt, że najważniejsze dzieła Platona O państwie i Prawa nie miały krajowych edycji. Były jednak wielokrotnie cytowane przez polskich pisarzy politycznych np. A.F. Modrzewskiego, S. Orzechowskiego, Ł. Górnickiego, F. Birkowskiego (z koncepcjami Platona można spotkać się także w dysertacjach uniwersyteckich i szkolnych np. Gimnazjum Gdańskiego).

W oparciu o dorobek Platona, Arystotelesa i Cycerona powstał Traktacik...o Rzeczypospolitej Jerzego Lemke, wydany trykrotnie w latach 1608-1632. Lemke zawarł w swym dziele krytykę omnipotencji stanu szlacheckiego i żądanie emancypacji mieszczaństwa, które jest ważnym ogniwem systemu ekonomicznego każdej organizacji państwowej.

Stosunkowo dużą popularnością wśród krajowych drukarzy (tylko w XVI wieku) cieszyly się mowy Demostenesa, z których można wymienić m.in. Oratio de libertate Rhodiorum, wydana w trzech edycjach w latach 1521-1547 oraz Oratio de pace, opublikowana dwukrotnie w latach 1531-1546.

Jednak w źródłach bibliograficznych najczęściej występują pisarze antycznego Rzymu, szczególnie Cyceron autor m.i.n.: Somnium Scipionis...de Republica, dwa wy dania z lat 1511-1527. Dużą liczbą wydań cieszyły się Epistolae familiares (inny tytuł Epistolarum familiarum) opublikowane $w$ najmniej jedenastu edycjach $z$ lat 1510-1685. Z pism filozoficznych ukazały się De officis, dziesięć wydań w latach 1512-1575 i dziewięć edycji pt. Officia Ciceronis w latach 1516-1680, przetłumaczone i wydane pt. O powinnosciach wszech stanów ludzi w czterech edycjach z lat 1575-1606. Wśród opublikowanych mów należy wymienić Pro rege...ad Caesarem oratio, dwa wydania z lat 1518-1531 i Pro lege Manilia..., trzy wydania z lat 1531-1610.

Wśród wielu krajowych opracowań twórczości Cycerona znalazło się m.in. dzieło Jana Marcina Ujazdowskiego In orationem Ciceronis...commentarius z 1587 roku, oparte na pracach Paulusa Manutiusa, C. Sigonio i E. Hotmana.

Pewien wpływ na postawe polityczną, światopogląd czytelników mogły mieć także pisma filozoficzno-moralne Seneki, z których opublikowano m.in. Formula honestae vitae, w pięciu edycjach z lat 1524-1582; Opera w dwóch edycjach z lat 1529-1557 oraz Epistolae, w czterech edycjach do 1627 roku.

Myśli tego autora byly podstawą dla Łukasza Górnickiego do refleksji nad stanem Rzeczypospolitej w dziele Rzecz o dobrodziejstwach z Seneki wzięta z 1593 roku.

W analizowanych księgozbiorach szlacheckich można znaleźć od kilku do kilkudziesięciu pozycji z działu literatury antycznej. W bibliotekach reprezentowanych m.in. przez księgozbiór M.Grabskiego występowały przede wszystkim polonika (np. Officia Ciceronis), w liczbie co najwyżej kilku tytułów. W większych księgozbiorach dział piśmiennictwa omawianego typu jest znacznie bogatszy, 
obejmując często dzieła wydane w opracowaniu krytycznym takich autorów jak: Aldus Manutius, lustus Lipsius, I. Casaubon, Julius Pacius czy J.C. Scaliger. Były to zwykle publikacje zagraniczne.

Najczęściej spotykani autorzy to: Seneka (biblioteki: S. Lubienieckiego, Ł. Opalińskiego, S.K. Bieniewskiego, J. Dzieduszyckiego i J.A. Stadnickiego) i Cyceron np. De legibus rejestrowane przez inwentarz księgozbioru J.Sobieskiego. $Z$ dzieł Arystotelesa należy wymienić Politica (biblioteki: K. Drohojowskiego, J.A. Stadnickiego i J. Sobieskiego), natomiast dzieła zebrane Platona znalazly się w zbiorach $七$. Opalińskiego i H. Pinocciego.

Omawiane księgozbiory rejestrują także polonika, m.in. Polityka Aristotelesowe S. Petrycego (biblioteki Ł. Opalińskiego i H. Pinocciego).

Wiek XVII-ty przyniósł w Europie Zachodniej ważne osiągnięcia w zakresie teorii państwa, rozwijając koncepcje ujmujące krytycznie dorobek intelektualny antyku, średniowiecza i czasów późniejszych w tej dziedzinie, o ile stał on w sprzeczności z nowymi potrzebami. Geneza owych przewartościowań tkwiła w twórczości najwybitniejszych pisarzy politycznych Renesansu.

Ogólnie mówiąc, ukształtowały się dwa podstawowe kierunki myślenia: arystotelizm który determinował władzę królewską w sposób ograniczający jej naturę i uprawnienia i kierunek odmienny, dążący do uzasadnienia absolutnej i nieograniczonej władzy monarszej. Wiążą się z tym $\mathrm{m}$.in. kwestie racji stanu, umowy społecznej czy tolerancji religijnej.

Warto więc przyjrzeć się w jakim stopniu europejski dorobek w omawianej dziedzinie znalazł swe odbicie w krajowym repertuarze wydawnicznym, jeśli chodzi o twórczość najwybitniejszych pisarzy politycznych (biorąc pod uwagę nie tylko przedruki dzieł ale także ich recepcje)).

Z autorów szesnastowiecznych należałoby wymienić przede wszystkim Niccolo Machiawellego. Dzieła autora Księcia (objęte indeksem ksiąg zakazanych) nie miały polskich edycji, mimo to były znane. Świadczą o tym m.in. publikacje: Responsio Nicolai Ziemecki ad...Anonymi Jerzego Tyszkiewicza z 1610 roku, Institutionum rei militaris (cztery wydania z lat 1639-1646) i Reformacja obyczajów polskich z 1650 roku Szymona Starowolskiego, Cnoty cel nie ów do którego zmierza Machiawell... Krzysztofa Piekarskiego z 1662 roku, Śmierć pańska...Pawła Jana Sapiehy z 1667 roku Stanisława Tupika, Proiecta poetica Jana Vodassi z 1676 roku czy Classicum wolności polskiej Wojciecha Węgierskiego z 1703 roku. Warto podkreślić, że w większości przypadków autorzy polscy odnosili się negatywnie do makiawelizmu co było charakterystyczne dla całego okresu staropolskiego. Duża rolę w popularyzacji idei Machiawellego odegrał m.in. I. Lipsius - również on krytycznie oceniał tezy Księcia - jeden z najwybitniejszych teoretyków nowożytnego państwa. W Polsce ukazaly się wyłącznie tłumaczenia jego prac, mianowicie: O stałości ksiąg dwoje Janusza Piotrowicza, dwie edycje do 1649 roku (w 1599 roku ukazało się tłumaczenie niemieckie tego dzieła) i Politica pańskie Pawła Szczerbica, dwa wydania z lat 1595 i 1608 roku, ponadto źródła bibliograficzne informują o licznych cytowaniach z różnych dzieł Lipsiusa np. lusti Lipsii epistolica... Jana Mochingera lub Mendecas...ex...lib. Pol. Arist. de fundamento republicae...et...de monarchia... Chrystiana Laurentego Somnitza. Pisarstwo Lipsiusa 
reprezentowało kierunek arystotelesowsko-tomistyczny; był teoretykiem ustroju republikańskiego.

Odmienny nurt reprezentował Jean Bodin, teoretyk i gorący propagator ustroju monarchii absolutnej. W przeciwieństwie do Lipsiusa dzieł Bodina nie wydawano na terenie Rzeczypospolitej. Jego prace wykorzystali w swoich publikacjach m.in. Jan Łasicki w Pro Wolano...defensori adversus Antonio Possevino... z 1584 roku, z J. Bodinem polemizowat Szymon Starowolski w Discurs obtrectas Poloniae, Andrzej Wargocki w Apologii... z 1605 roku i Stanisław Wyliam w Disputatio politica... z 1649 roku.

Spośród wybitnych autorów szesnastowiecznych reprezentujących teorię teokratycznej organizacji państwa źródla bibliograficzne odnotowują przede wszystkim pisarzy katolickich, takich jak np. Roberto Bellarmino autor Compendium doctrinae christianae, dwa wydania z 1606 i 1655 roku i Apologia... z 1610 roku (jedna z najważniejszych pozycji tego autora De officio principis christiani nie miała krajowej edycji) czy Franciscus Suarez cytowany przez Jerzego Tyszkiewicza w Vindiciae doctrinae Societ. lesuz 1611 roku.

Poglądy protestanckie reprezentuje tutaj m.in. dzieło J. Kalwina O zwierzchności świeckiej... wydane w 1599 roku i liczne cytowania prac Filipa Melanchtona.

W przebadanych źródlach bibliograficznych nie udało się odnaleźć informacji na temat tak ważnych pisarzy politycznych XVI wieku jak monarchomachowie: np. G. Buchanan, Juan de Marcana czy Etienne Böetie (występowali przeciwko bezwzględnej podległości władzy królewskiej broniąc suwerenności i praw rządzonych) i utopiści: Thomas Campanella i Francis Bacon.

Wiek siedemnasty w Europie to okres rozwoju teorii umowy społecznej zakladającej, że podstawy władzy politycznej tkwią w woli jednostek, a nie w autorytecie prawa boskiego. W oparciu o konstrukcję umowy społecznej powstały prace poświęcone teorii państwa takich pisarzy jak m. in.: wielokrotnie cytowany w różnych traktatach politycznych i prawnych autorów krajowych Hugo Grotius (z jego dziet w Polsce opublikowane tylko Epistolae ad Israelem(!) Jaski z 1670 roku); Baruch Spinoza, którego Tractatus theologico-politicus nie doczekał się krajowej edycji ale mógł być znany (przynajmniej w sferach naukowych i intelektualnych) tak jak znana była jego Etyka, o czym świadczy rozprawa Jana Gotliba Möllera Benedictum de Spinoza ex ethices...demonstratae z 1696 roku; Thomas Hobbes cytowany przez Chrystiana Fryderyka Büchera w traktacie Regnum Dei per naturam a falsis Thomae Hobbes hypothesibus z 1686 roku i przez Godfryda Königa w rozprawie Dissertatio de regibus civitatis in genere z 1675 roku.

Pod wpływem T. Hobbesa (a także J. Bodina) powstawała koncepcja państwa Samuela Pufendorfa zwolennika władzy absolutnej, której podstawą miała być umowa społeczna $^{28}$. Dzieła Pufendorfa (poza Puncta transactione, cztery wyd. z 1659 roku) nie były w kraju przedrukowywane, ale ilość informacji bibliograficznych dotyczących tego pisarza jest znaczna. Przede wszystkim należy wymienić prace Ernesta Königa Introductio ad libros...Samueli Pufendorfi de officio hominis... z 1676 roku i Sam. Pufendorfi liber de officio hominis, wydana dwukrotnie w latach 1679 i 1682.

Ideologię absolutystyczną głosili m.in. John Barclay i Hermann Conring. Z dziet J. Barclaya na terenie Rzeczypospolitej ukazały się tylko: Paraenesis ad sectarios 
huius temporis de vera Ecclesia... wydana dwukrotnie - w tłumaczeniu $t$. Górnickiego w 1628 i w wersji łacińskiej w 1695 roku oraz fragment Icon animorum wydany w wierszowanej broszurce w 1647 i 1684 roku. Na nieprzychylny obraz Rzeczypospolitej zawarty w Icon... odpowiedział Ł. Opaliński w Polonia defensa z 1648 roku $^{29}$. Publikacje H. Conringa związane z Rzeczypospolitą to m.in. wstęp do Polonii S. Starowolskiego (wydania: Wolfenbütel 1656 i Gdańsk 1669) oraz Enarratio causarum ob quas...Carolus Gustavus...coactus est Regem Poloniam bello adorriri, wydanie krajowe z 1656 roku. Polemikę z poglądami H. Conringa podjęli: Jan Toński, w In iustitia armorum Sveciorum in Polonia z 1656 roku i Jan Sachs w De scopo Republicae Poloniae adversum Hermannum Conringium.

Wybitnym autorem XVII wieku, który nawiązywał do teorii J. Lipsiusa, kontynuując arystotelesowsko-tomistyczne tradycje Lowanium był E.Puteanus. Z jego dzieł wydano Civilis doctrinae lineae quibus Aristotelis Politicorum... i Politica Aristotelis continuis aphorismi... (obie edycje z 1646 roku).

Kończąc warto dodać, że kwerenda bibliograficzna nie przyniosła informacji na temat takich autorów jak loannes Althusius, Wilhelm Gottfried Leibnitz, Gabriel Naudé czy Claude Saumaise, I. Arnisaeus.

Należy zaznaczyć, że wyżej przedstawiona analiza obecności najwybitniejszych europejskich pisarzy politycznych w literaturze polityczno-prawnej badanego okresu, ma charakter niepełny, wyrywkowy, gdyż została oparta na niekompletnych danych bibliograficznych.

Nowożytne koncepcje europejskie w dziedzinie nauki o państwie znalazły swoje odbicie w dużych księgozbiorach szlacheckich. Przede wszystkim należy wymienić prace J. Lipsiusa - zwlaszcza Politicorum..., które występowały w bibliotekach: S. Lubienieckiego, Ł. Opalińskiego, H. Pinocciego, S.K. Bieniewskiego, J.A. Stadnickiego, J. Sobieskiego i według J. Długosza - u Zasławskiego ${ }^{30}$.

Znacznie skromniej reprezentowane były dzieła J. Bodina. De Republica znane było H. Pinocciemu a także Ł. Opalińskiemu o czym świadczy obecność w jego księgozbiorze Synopis sive medula in sex libri J. Bodini...De Republica Johanna Werdenhagena. W księgozbiorze J. Sobieskiego znalazło się natomiast Universa naturae theatrum.

W omawianych księgozbiorach znalazły się także ślady znajomości // Principe N. Machiawellego: posiadał go J. Dzieduszycki a w księgozbiorze $Ł$. Opalińskiego występowala praca Pedro Ribadeneiro Trattato contra qvello che Niccolo Machiawelli. Inne dzieło najwybitniejszego pisarza politycznego doby Renesansu, Sztukę wojenną rejestrował inwentarz biblioteki J. Sobieskiego.

Można spotkać tutaj także dzieła utopistów: De philosophia T. Campanelli (księgozbiory H. Pinocciego i J. Sobieskiego) i Utopia T. Morusa (biblioteka J. Sobieskiego).

Należy przypomnieć autorów parenez katolickich, którzy występowali m.in. przeciwko teorii racji stanu Machiawellego, tolerancji religijnej i głosili pochwałę teokratycznej formy państwa. Należar do nich obok wspomnianego P. Ribandeneiro m.in. Carolus Scribanius, autor Instituto Politico-Christiana (biblioteka Łukasza Opalińskiego). 
Z autorów siedemnastowiecznych najbardziej ceniono Hugo Grotiusa, którego różne dzieła znalazły się w bibliotekach: S. Lubienieckiego, Ł. Opalińskiego, $\mathrm{H}$. Pinocciego, A.M. Lubomirskiego, J. Stadnickiego i J. Sobieskiego.

Inne dzieła, które warto wymienić to Elementa philosophica de cive T. Hobbesa (księgozbiór H. Pinocciego), Civilis doctrinae E. Puteanusa (księgozbiór Ł. Opalińskiego), Doctrina politica I. Arnisaeusa (księgozbiór S.K. Bieniewskiego).

W księgozbiorach omawianego typu występowały także licznie publikacje o charakterze parenetycznym np. Le ministre... Jeana Silhona (biblioteki H. Pinocciego i J. Sobieskiego) oraz Principis christiani archetypon politicum... Athanasiusa Kirchera (biblioteka A.M. Lubomirskiego).

Kolejną grupę druków pochodzenia zagranicznego stanowiły swego rodzaju wydawnictwa informacyjne jakimi były tzw. tezaurusy polityczne np. Tesoro politico wydany w Kolonii, rejestrowany przez inwentarz księgozbioru $Ł$. Opalińskiego lub wydawnictwo o tym samym tytule (edycja z Tours), które posiadar H. Pinocci.

Jeszcze innym rodzajem publikacji polityczno-prawnych omawianego typu byly zbiory aforyzmów (funkcjonujące także $w$ rodzimym piśmiennictwie politycznym $n p$. Monita politico-moralia Andrzeja Maksymiliana Fredry). Podobne wydawnictwa zawierające elementy refleksji teoretycznej, służyły jednocześnie jako zbiory tekstów retorycznych. Jako przykłady mogą tu posłużyć prace Juliusa W. Zinckgreffa Emblemata ethico-politicorum (księgozbiór A.M. Lubomirskiego) i Jeana Chokiera de Surlet Thesaurus politicorum aphorismum (biblioteka Ł. Opalińskiego). Charakterystyczne jest to, że jednym z kilku tytułów zagranicznych jakie znalazhy się w księgozbiorze M. Grabskiego, był właśnie druk tego typu - Aforismi politici... Mateo Bacceliniego.

Problemy kompetencji, zakresu władzy królewskiej i jej prawnego upełnomocnienia, społeczeństwa itp. znalazły naturalnie silne odbicie w piśmiennictwie krajowym badanego okresu, przy czym największy dorobek w zakresie refleksji teoretycznej przyniósł okres do połowy XVII wieku. Do publikacji, które osiągnęły największą liczbę wydań należą: De republica emendanda Andrzeja Frycza Modrzewskiego (dwa wydania krajowe i dwa zagraniczne w latach 1551-1557, przy czym edycje krajowe były niepelne) i De libero hominis arbitro, wydane trzykrotnie w Bazylei w latach 1613-1615; O wolności Korony Polskiej... M. Stryjkowskiego, Złota wolność Korony Polskiej podpisywana kolejno przez W. Chlebowskiego i J.K. Dachnowskiego, publikacje wydane pięciokrotnie w latach 1575-1630; Paradoxa, cztery wydania w latach 1579-1601, w tym dwa zagraniczne, Pro Christo fide et Petri sede..., cztery edycje w latach 1583-1600 - dziela Krzysztofa Warszewickiego; Stanislai Orechovi Apocalipsis facies perturbatae Reipublicae (tłumaczenie polskie Wizerunek utrapionej Rzeczypospolitej...) Jana Dymitra Solikowskiego, dzieło wydane dziesięciokrotnie w latach 1580-1696; Fidelis subditus sive de institutio regia Stanisława Orzechowskiego, pięć edycji w latach 1584-1698; Exorbitacje albo o rzeczach $w$ każdym królestwie i rzeczypospolitej potrzebnych Piotra Wężyka Widawskiego, wydane w trzech edycjach w latach 1603-1649; De optimo Reipublicae statu Jerzego Ossolińskiego, dzieło opublikowane w zbiorze Orationes, trzykrotnie w latach 1647-1686.

Wymienione wyżej publikacje łączą w sobie wątki refleksji teoretycznej z treściami publicystycznymi, odnoszącymi się do aktualnych problemów rzeczywi- 
stości politycznej Rzeczypospolitej. Powyższe zestawienie wskazuje, że zdecydowanie największą liczbą wydań cieszyły się dzieła wyrażające akceptację ustroju państwa jako monarchii stanowej, w której pełnią praw politycznych cieszył się wyłącznie stan szlachecki. Ten typ ustroju można określić mianem monarchii mieszanej, zorganizowanej na zasadzie wzajemnego współwystępowania instytucji republikańskich, oligarchicznych i monarchicznych. Aprobata modelu rozwiazań ustrojowych łączyła się równocześnie z krytyczną oceną funkcjonowania urządzeń państwowych. Za zły stan państwa obarczono odpowiedzialnością szlachtę. Z tego względu właśnie w odrodzeniu moralnym szlachty widziano sposób na sanację instytucji republikańskich państwa (S. Orzechowski, P. Wężyk Widawski) postulując równocześnie wzmocnienie władzy królewskiej kontrolowanej przez Kościół katolicki (K. Warszewicki).

Koncepcje polityczne sformułowane przed 1650 r. znalazły swoją kontynuację w piśmiennictwie okresu późniejszego. Największą liczbą wznowień cieszyły się dzieła: A.M. Fredry Monita politico-moralia, wydane w ok. jedenastu edycjach zagranicznych w latach 1664-1727; Kazimierza Zawadzkiego Tractatus super ad verentiam defectum in captibus imperii Sarmatici, cztery wydania (w tym jedno zagraniczne) z lat 1676-1716; Stanisława Herakliusza Lubomirskiego Rozmowy Artaxesa $i$ Ewandra, cztery wydania $z$ lat 1683-1718, tegoż Adverbiorum moralium... wydane siedmiokrotnie w latach 1688-1716 i De vanitate consiliorum (polskie wersje to: Zbawiennych środków książeczka i Próżność i prawda rady) wydane w czternastu edycjach w latach 1699-1728; Jana Stanisława Jabłonowskiego Skrupuf bez skrupułu, dwa mydania z 1730 roku. Piśmiennictwo reprezentowane przez wyżej mymienione tytuly nie odbiega $w$ warstwie merytorycznej od poprzedniego okresu. Uznając za idealny ustrój Rzeczypospolitej, upatruje jednocześnie przyczyny kryzysu państwowości polskiej w degeneracji moralnej szlachty (uderza przy tym pesymizm w ocenie szlachty jako potencjalnej siły sprawczej procesu reform państwa). Zwraca natomiast uwage mala ilość nowych, oryginalnych utworów opublikowanych po 1660 roku) zwłaszcza w latach 1700-1732.

Niewielką grupę wśród traktatów politycznych stanowiły dzieła o charakterze naukowym, pozbawione w zasadzie treści publicystycznych. Powstały one zwykle w środowisku uczonych zwiazanych z takimi ośrodkami jak Gdańsk, Toruń czy Elbląg. Można tutaj wymienić wielu autorów m.in. Piotra Oelhafiusa, Jana Nixdorfa, Samuela Schelgwiga, Jana Krzysztofa Rosteuschera, czy J.K. Hartknocha. Przykładem takiej pracy były Systemae politicae... Batłomieja Keckermana - wydane w czterech zagranicznych edycjach w latach 1606-1616.

Dosyć często wśród traktatów politycznych można spotkać dzieła o charakterze parenetycznym, takie jak: Totius philosophiae Henryka Wildenberga, sześć wydań w latach 1548-1571, w tym jedno krajowe (druk zawiera wzorce monarchy, posła itp.); De optimo senatore Wawrzyńca Goślickiego, trzy wydania z lat 15681593; De legato et legatione K. Warszewickiego, pięć wydań z lat 1595-1646, w tym jedno zagraniczne i Regum et principium... tegoż autora, wydane w trzech edycjach (dwie zagraniczne) z lat 1603-1608; Bellator christianus... Mateusza Bembusa, cztery wydania w tym jedno zagraniczne w latach 1617-1688 oraz De bono et malo... Wojciecha Tylkowskiego, wydane w dwóch edycjach z lat 1690-1691. 
Wśród wymienionych publikacji zawierających próby określenia wzorca idealnego monarchy, męża stanu czy obywatela, przeważają parenezy katolickie.

Analizując inwentarze bibliotek szlacheckich można stwierdzić, że niezależnie od ich rodzaju, zawieraly one szeroką reprezentację piśmiennictwa krajowego z omawianej dziedziny. Można wymienić np. De Republica... A.F. Modrzewskiego (biblioteki H. Szembeka i J.A. Stadnickiego), Quincunx to jest wzór Korony Polskiej... S. Orzechowskiego (księgozbiory: J. Lorkowskiej, H. Szembeka i H. Pinocciego) czy De optimo Reipublicae statu Jerzego Ossolińskiego (biblioteki Ł. Opalińskiego, H. Pinocciego oraz zapewne A.M. Lubomirskiego, który odziedziczył duży zbiór rękopiśmiennych dzieł kanclerza w tym trzy zbiory mów).

W drugiej połowie XVII wieku największą popularnością cieszyły się Monita politico-moralia A.M. Fredry obecne w bibliotekach H. Pinocciego, A.M. Lubomirskiego, M. Grabskiego, J. Dzieduszyckiego i J. Sobieskiego. Ponadto według H. Bogdanow ${ }^{31}$ Monita znalazły się także w pięciu inwentarzach księgozbiorów szlachty krakowskiej.

Z dzieł parenetycznych można wymienić m.in. Dworzanina polskiego Ł. Górnickiego (biblioteki S. Sapińskiego, Ł. Opalińskiego i H. Pinocciego), De consilio (biblioteka J. Sobieskiego) i De legato... (biblioteka J.A. Stadnickiego) K. Warszewickiego, De institutione principis Henryka Martiniego (biblioteka A.M. Lubomirskiego) oraz Theatrum politicum quod agendum sit a principe Ambrożego Marlaniego (księgozbiór M. Grabskiego).

\section{b) Publicystyka}

Jak już wspomniano wydawnictwa tego typu zdecydowanie górują liczebnością w zbiorze publikacji politycznych. Największą ilość wydań osiągnęły następujące tytuły: Rozmowa...o wolnościach i prawach polskich, Ł. Górnickiego, wydana trzykrotnie do 1616 roku pod różnymi tytułami (jej uzupełnieniem była Droga do zupełnej wolności... wydana dopiero w 1650 roku); Sejm niewieści... satyra Marcina Bielskiego, trzy edycje w latach 1586-1639; Kazania sejmowe zamieszczone w zbiorze Kazania na niedzielę i święta, pięć wydań w latach 1597-1618 iw Kazaniach zołnierskich, cztery wydania w latach 1677-1688, Wzywanie do pokuty obywatelów Korony Polskiej, sześć wydań z lat 1610-1715 - utwory Piotra Skargi; Cenzor obyczajów niektórych... Jana Januszowskiego, cztery edycje z lat 1607-1628; Prywata Polską kieruje, trzy wydania z lat 1624-1649, Poprawa niektórych obyczajów polskich i Reformacja obyczajów polskich, cztery wydania z lat 1625-1692 utwory Szymona Starowolskiego; dramat Nędza z biedą z Polski idą, co najmniej pięć wydań w XVII wieku; Satyr na twarz Rzeczypospolitej Samuela Twardowskiego, trzy edycje z 1640 dwie z 1645 roku; Satyr nowy z chorej glowy lub Satyr polski wraca się z Bukowiny, cztery edycje wydane zapewne po klęsce piławieckiej (1649 rok); Satiri albo przestrogi do naprawy rządu...w Polsce Krzysztofa Opalińskiego, wydane pod różnymi tytułami w dziewięciu edycjach w latach 1650-1698.

Wyżej wymienione publikacje tradycyjnie, zgodnie $z$ utartą konwencją, ujmowały problematykę polityczną w kategoriach etycznych, piętnując złe obyczaje, negatywne strony życia politycznego i społecznego państwa. Szczególną uwagę 
poświęcano destrukcyjnej roli szlachty. W związku z tym przeważały opinie postulujące np. zwiększenie kompetencji senatu i wzmocnienie władzy królewskiej (P. Skarga i Szymon Starowolski) przy zachowaniu systemu monarchii mieszanej i dominującej roli Kościoła katolickiego w państwie.

Część wydawnictw publicystycznych poświęcona była stosunkom państwoKościół, problemom wyznaniowym (ok. $3 \%$ ogółu publikacji politycznych). Należały do nich: De controversis inter ordinem ecclesiasticum et secularum in Polonia... Laurentego Faunteusa, wydane trzykrotnie w latach 1587-1632 (dzieło stanowiło podsumowanie całości pretensji Kościoła wobec państwa); Informacje o niektórych artykułach między duchownym a świeckim stanem Mikołaja Dobrosielskiego, trzy edycje z lat 1607-1632; Decas quaestionum publicarum Regni... Andrzeja Lipskiego, pięć edycji w latach 1616-1647; $O$ exorbitacjach stanu duchownego oraz 0 exorbitacjach panów świeckich Macieja Smogleckiego, trzy wydania w latach 1619-1632; Stacje żołnierskie S. Starowolskiego, pięć wydań w latach 1623-1638.

Przytoczone tytuły prezentują wyłącznie punkt widzenia duchowieństwa (w takich kwestiach jak np. dziesięciny, sądy duchowne, opodatkowanie Kościoła na rzecz państwa). Publikacje wymierzone przeciwko duchowieństwu ukazywaly się rzadko, w pojedyńczych anonimowych edycjach (do wyjątków należały takie utwory jak Monita privata... Hieronima Zahorowskiego, utwór antyjezuicki wznawiany pięciokrotnie w latach 1612-1662).

Do polemik międzywyznaniowych należały np. Proces konfederacjej... Piotra Skargi, pięć wydań z lat 1595-1615 oraz publikacje Daniela Ernesta Jabłońskiego wyrażające punkt widzenia dyssydentów Jura et libertates disidentum, sześć wydań zagranicznych w latach 1708-1720.

Kolejny typ druków publicystycznych to utwory zajmujące się wyłącznie lub w znacznej części stanem ekonomicznym Rzeczypospolitej, obejmujące ok. 0,7\% ogółu publikacji politycznych. Z kilkudziesięciu tytułów wznowienia miały jedynie dwa dzieła: Cena pieniędzy jaka być ma Jana Grodwangera, trzy edycje w latach 1631-1632 i Dyszkurs o pomnożeniu miast w Polszcze S. Starowolskiego wydany dwukrotnie w 1648 roku.

Obie publikacje nawiazując do koncepcji merkantylizmu, proponowały m.in. dokonanie zmian, dzięki którym nastąpi wzmocnienie gospodarcze miast i kupiectwa a więc rozwój przemysłu i eksport wytwarzanych produktów. Były to jedne z nielicznych szerszych ujęć problematyki. Zdecydowana większość wydawnictw tego typu poświęcona była wyłącznie kwestiom monetarnym.

Do swego rodzaju utworów publicystycznych można zaliczyć także paszkwile, popularną broń w walce politycznej. Przykładem takiego wydawnictwa może byś utwór Johanna Frischmana Animarum in Europa... wydany pięciokrotnie w 1656 roku w Upsali miał usprawiedliwić w oczach europejskiej opinii publicznej szwedzką agresję na Rzeczpospolitą. Druk Frischmana funkcjonował także w krajowym obiegu czytelniczym o czym świadczą inwentarze bibliotek szlacheckich.

Spośród utworów publicystycznych, które znalazły się w księgozbiorach szlacheckich szersze ujęcie reprezentują: Accusationes in Christophorum Zborovium actiones III Andrzeja Rzeczyckiego (księgozbiory S. Sapińskiego i H. Pinocciego z tym, że dzieło Rzeczyckiego w bibliotece Pinocciego występowało w dziale Libri 
Istoricl), Reformacja obyczajów... S. Starowolskiego rejestrowana przez inwentarze bibliotek M. Grabskiego i J.A. Stadnickiego, Polonia defensa... Ł. Opalińskiego (biblioteki Ł. Opalińskiego i H. Pinocciego), Perspectiva politica Regno Poloniae elaborata A. Korycińskiego w księgozbiorach M. Grabskiego i S.K. Bieniewskiego oraz De vanitate consiliorum S.H. Lubomirskiego, które obecne było w ośmiu inwentarzach bibliotecznych szlachty krakowskiej.

W większości księgozbiorów można znaleźć także jakąś pozycję zawierającą polemikę wyznaniową np. Mowy Andrzeja Chryzostoma Załuskiego, w których autor występował przeciwko równouprawnieniu obywatelskiemu dyssydentów, obecne w zbiorze M. Grabskiego i w księgozbiorach szlachty krakowskiej.

Przykładem druku dotyczącego stosunków państwo-Kościół jest Deklaracja albo zniesienie pretensji żolnierza z dóbr duchownych (biblioteka H. Pinocciego).

Problematyka stanu gospodarczego państwa znalazła odbicie w księgozbiorach pochodzących z drugiej połowy badanego okresu, co było związane z permanentnym kryzysem monetarnym w Polsce po 1660 roku. Kwestię upadku monety krajowej i skarbu państwa poruszały publikacje dotyczące tzw. sprawy Tytusa Liwiusza Boratyniego i Tynffa. Chodziło tutaj o domniemane nadużycia popełnione w trakcie emisji monety przez mennicę królewską, którą kierował w pewnym okresie Boratyni. Do tego typu druków należala m.in. Informacja o mennicy szelągowej Boratyniego (biblioteki A.M. Lubomirskiego i M. Grabskiego). Z pewnością, publikacja ta była znana także $\mathrm{H}$. Pinocciemu, który żywo interesował się podobną problematyką. W jego księgozbiorze znalazło się sporo prac drukowanych d rękopiśmiennych (także autorstwa samego Pinocciego) z dziedziny ekonomii.

Inne publikacje, o jakich można wspomnieć to anonimowy Dyskurs o teraźniejszym stanie żup solnych w bibliotece A.M. Lubomirskiego oraz Sposób jakim góry złote, srebrne... W Królestwie Polskim naprawić Wojciecha Gostkowskiego (biblioteka M. Grabskiego).

W części księgozbiorów (takich jak biblioteki Ł. Opalińskiego, S. Lubienieckiego, A.M. Lubomirskiego itp.) obok poloników występowala także publicystyka zagraniczna, którą zaliczono w niniejszym opracowaniu do działu historii krajów europejskich, np.: Pietra del paragone politico...maggiore monarchie T. Boccaliniego - utwór odnoszący się do stosunków hiszpańsko-włoskich na początku XVII-tego wieku (biblioteki H. Pinocciego i A.M. Lubomirskiegc) jak również Mars gallicus seu de iustitia armorum et foederum regis Galiae... C. Jansena (księgozbiór $Ł$. Opalińskiego).

\section{3) Druki o charakterze informacyjno-propagandowym}

Zespół druków tego typu obejmujący m.in. mowy sejmowe, diariusze, projekty ustaw i obrad sejmowych, listy repsonsy, manifesty, utwory okolicznościowe, relacje, wydawnictwa o charakterze prasowym itp. stanowił ok. $30 \%$ zbioru druków politycznych.

$W$ badanych księgozbiorach wydawnictwa $z$ omawianej dziedziny stanowity nieznaczny zbiór jeśli chodzi o duże biblioteki szlacheckie (wyjątkiem jest tutaj biblioteka H. Pinocciego - ok. 11\% całego zbioru pozycji politycznych, natomiast 
największy procentowy udział druków i rękopisów omawianego typu rejestruje księgozbiór A.M. Lubomirskiego - cztemaście tytułów czyli ok 16\%). Stosunkowo dużą ilość druków tego typu znalazała się w małych księgozbiorach szlacheckich np. w księgozbiorze S. Sapińskiego (ok. 16\%) a w księgozbiorze M. Grabskiego (ok. 18\%).

Ważną role w systemie informacji politycznej Rzeczypospolitej odgrywały tzw. Vota sejmowe (obok diariuszy, projektów ustaw i obrad sejmowych, instrukcji sejmikowych - druków nieurzędowych i urzędowych związanych z kampaniami i obradami sejmowymi). Pełnity one wiele funkcji. W chwili publikacji informowały czytelników o aktualnych problemach państwa będących przedmiotem obrad sejmowych i o decyzjach, które na sejmach zapadały. Równocześnie wyrażały poglądy mówców (pojawiały się tutaj wątki publicystyczne i propagandowe) oraz informowaly elektorat szlachecki o tym w jakim stopniu poseł stosuje się do instrukcji sejmikowych. Wraz z upływem czasu druki tego typu - wydawane w zbiorach jako podręczniki do nauki wymowy - mialy przygotować młodego szlachcica do aktywnej działalności politycznej, służąc za wzór retoryki politycznej. W dalszej kolejności vota stawały się ważnym źródłem wiedzy historycznej. Publikacje te wydawane były zwykle w pojedyńczych edycjach. Zadaniem drukarzy urzędowych i działających przy sejmach było m.in. publikowane głosów poselskich (często podobne wydawnictwa ogłaszane także nakładem własnym autora), dlatego nie ma sensu wymieniać tutaj poszczególnych tytułów. Można tylko podkreślić, że istnieje pewna prawidłowość: szczególnym dorobkiem w tej dziedzinie wyróżniali się aktywni dzjałacze polityczni wielokrotnie pełniący funkcje posłów, senatorowie i monarchowie.

Podobne funkcje (publicystyczne, informacyjne i propagandowe) petnily różnorakie listy, responsy, manifesty itp. Należy zaznaczyć, że wspomniane "listy" miały charakter dzisiejszych "listów otwartych".

Należały do nich np.: Epistola...ad Laurentium Gembicki Reinholda Heidensteina, wydane trzykrotnie w latach 1610-1712 czy Respons na list...Kasztelana Bydgoskiego Stanisława Kazimierza Dąbskiego wydany w co najmniej trzech edycjach w 1697 roku.

Publikacja S.K. Dąbskiego jest typowym drukiem związanym z walką polityczną w trakcie elekcji. Inny tytuł tego rodzaju to np. Cenzura candidatorum... Andrzeja Olszowskiego wydana w latach 1669-1670, w liczbie jedenastu edycji.

Oczywiście, nie tylko elekcje były przyczyną wzmożonej produkcji wydawniczej w zakresie publikacji informacyjno-propagandowych. Dotyczy to wszystkich ważniejszych wydarzeń politycznych np. przyjęcie przez Jerzego Ossolińskiego tytułu książęcego wywołało natychmiastową reakcję szlacheckiej opinii publicznej. M.in. ukazała się wtedy publikacja Adama Grodzieckiego Przestroga o tytułach, dygnitarstwach cudzoziemskich w Polskim Królestwie wydana w trzech edycjach z lat 1634-1637 (przyjmowanie obcych tytułów, orderów dworskich itp. stanowiło w opinii szlacheckiej zaprzeczenie - chociażby tylko nominalnej-zasady równości).

Inne publikacje o charakterze okolicznościowym to np. takie tytuły jak: Kolęda moskiewska, to jest wojny moskiewskiejprzyczyny słuszne... a nadzieja zwycięstwa wielka Pawła Palczowskiego z 1609 roku, czy Bij Gustawa kto dobry Kaspra Twardowskiego z 1629 roku. 
Druki tego typu pojawiające się zwykle w okresie wojen toczonych przez Rzeczpospolitą, można zaliczyć do dużego zespołu publikacji z zakresu propagandy patriotyczno-wojennej.

Z konfliktami zbrojnymi łączyły się tzw. relacje i nowiny: Szturm smoleński sobotni z 1611 roku Jana Krajewskiego, anonimowa Relacja bitwy... z 1620 roku, Relacja prawdziwa o wejściu Wojska Polskiego do Wołoch Teofila Szemberga, trzy wydania z 1621 roku, Relacja expedycjej zbaraskiej Marcina Kuczwarewicza z 1650 roku.

Obok nowin, awiz i relacji, w drugiej połowie wielu XVII pojawiły się już wydawnictwa periodyczne np. Wiadomości różne cudzoziemskie wydawane od 1679 i Mercurius Polonicus wydawany od 1661 roku.

Wśród publikacji propagandowych jako odrębny, zwarty zespół można wyróżnić utwory antytureckie (ok. 1,7\% zbioru druków). Wydawnictwa tego typu to m.in. De bello adversus Turcas, sześć wydań w latach 1543-1663 i Turcica secunda, pięć edycji w latach 1544-1663, w tym dwie zagraniczne - prace Stanisława Orzechowskiego; Deliberacja o spolku(!) i zwiazku Korony Polskiej Jakuba Ponętowskiego, cztery wydania w latach 1595-1646, poświęcona projektom utworzenia ligii antytureckiej; Pobudka...do wojny przeciw Turkom i Tatarom, dwie edycje z 1596 roku i wiele innych utworów Józefa Wereszczyńskiego oraz De pace inter...belloque Turcis Szymona Starowoiskiego, cztery edycje z lat 1645-1669.

Poszczególne księgozbiory szlacheckie rejestrują przynajmniej po jednym tytule każdego typu publikacji informacyjno-propagandowych. I tak np. w inwentarzu biblioteki S. Sapińskiego znalazło się Oratio X. Kardynała Radziwilla a w księgozbiorze A.M. Lubomirskiego rękopiśmienne mowy kanclerza Jerzego Ossolińskiego. Utwory o charakterze propagandowym mogą reprezentować m.in. Jawnej niewinności manifest Jerzego Lubomirskiego (biblioteki A.M. Lubomirskiego i H. Pinocciego) oraz Cenzura candidatorum... A. Olszowskiego (biblioteki Ł. Opalińskiego i $\mathrm{H}$. Pinocciego). W księgozbiorze $\mathrm{H}$. Pinocciego nie zabrakło także Przestrogi... Adama Grodzieckiego. Propagandę wojenną reprezentuje Pole marsowe Jana Żukowskiego przeciwko królowi szwedzkiemu..., odnotowane w inwentarzu biblioteki A.M. Lubomirskiego. Z relacji, można wymienić tutaj List o oblężeniu zamku Dinamentu (biblioteka S. Sapińskiego) i Diariusz z oblężenia wiedeńskiego (biblioteka M. Grabskiego).

Ogólnie mówiąc, liczba zachowanych wydawnictw prasowych, relacji, nowin $w$ badanych księgozbiorach jest nieliczna (ulegały często zniszczeniu, zagubieniu bądź „zaczytaniu” lub nie były w ogóle w inwentarzach wymieniane). Charakterystyczne jest to, że w dużych bibliotekach szlacheckich obok poloników występowały także publikacje zagraniczne np. „Journal de savans..." (u H. Pinocciego, A.M. Lubomirskiego i J. Sobieskiego) jedno z pierwszych czasopism naukowych zajmowało się m.in. historią - w Europie. Oprócz tego można wymienić następujące tytuly: Relation exacte des choses passes dans les assuntes quae le roi de Suede fit donner a Copenhagen z 1659 roku (biblioteka A.M. Lubomirskiego) i Awizy różne z cudzych krajów po niemiecku drukowane. Mógł to być druk zagraniczny lub krajowy (gdański) albo gazetka pisana. Awizy znalazły się w księgozbiorze $\mathrm{H}$. Pinocciego. 
Wśród publikacji zawierających treści propagandowe największą ilość w omawianych księgozbiorach stanowią druki antytureckie (przede wszystkim polonika ale w dużych bibliotekach także wydawnictwa pochodzenia zagranicznego) i antytatarskie. Sa to m.in.: Di despotino de Turcarum moribus... Barttomieja Georgiejewicza (biblioteka S. Sapińskiego), Ad principes populumque chrystianum de bello adversus Turcos... Gulielmusa Brussiusa (biblioteka Ł. Opalińskiego), Turcica secunda S. Orzechowskiego (biblioteka A.M. Lubomirskiego), Brat Tatar albo liga wilcza... Jana Białobłockiego (biblioteka H. Pinocciego) oraz Pobudka na zniesienie Tatarów Perekopskich S. Starowolskiego (biblioteka M. Grabskiego).

\section{4) PODRĘCZNIKI DO NAUKI WYMOWY JAKO NARZĘDZIE KSZTAŁTOWANIA KULTURY POLITYCZNEJ STANU SZLACHECKIEGO}

Publikacje z tej dziedziny stanowią ok. 4\% druków politycznych. Wśród nich można wyróżnić dwie podstawowe grupy: traktaty o charakterze teoretycznym, naukowym oraz publikacje zawierające zbiory mów politycznych.

$W$ analizowanych księgozbiorach podobne tytuly stanowia przeciętnie od 6 do $9 \%$ - w bogatszych księgozbiorach szlacheckich (biblioteki Ł. Opalińskiego, $\mathrm{H}$. Pinocciego, J. Sobieskiego a także S. Lubienieckiego).

Inwentarze S. Sapińskiego, M. Grabskiego i H. Szembeka rejestrują tylko kilka pozycji z tej dziedziny (najwięcej druków tego typu - cztery tytuly czyli ok. 7\% znalazło się w bibliotece M. Grabskiego).

\section{a) Traktaty retoryczne}

Podstawowym źródłem nauczania retoryki (obejmującej m. in. elementy wiedzy historycznej, w tym heraldyki i polityki ${ }^{32}$ ) była klasyka. Na terenie Rzeczypospolitej ukazały się m.in. De arte rhetorica libri tres... Carlo Sigonio interprete z 1577 roku Arystotelesa; Dialogus de... oratoria Regia z 1515 roku, Comentariorium rhetoricum, dwa wydania z 1527 i 1539 roku Cycerona (nie było pełnego krajowego wydania De oratore, Partitiones oratoriae ani Orator tegoż autora).

Jako przykłady nowożytnych opracowań dorobku pisarzy antycznych mogą posłużyć dzieła (obok wspomnianych wyżej prac Adama Romera) m.in. Andrzeja Franckenbergera Norma enarrandi ac... oratores Demosthenem et... Ciceronem... z 1570 roku i Barttomieja Duczymińskiego Exercitium rhetoricum ad exemplum primae Ciceronis Philippicae ad Mar. Antonium... z 1619 roku.

Ponadto dzieła Arystotelesa, Cycerona czy Kwintyliana wykorzystano w takich traktatach jak: Systema rhetoricae Bartomieja Keckermanna, wydane czterokrotnie w latach 1608-1618; De arte rhetorica libri tres, ex Aristotele, Cicerone etc., osiem wydań w latach 1645-1706, Compendium rhetoricae, siedem edycji w latach 1703-1727, Tabulae rhetoricae, sześć wydań w latach 1714-1730 - dzieła Cypriana Suareza; Praecepta artis rhetorices... Zygmunta Lauxamina, dwanaście edycji w latach 16481732; Orator... Michała Radaua, dwadzieścia wydań w tym dwa krajowe z lat 1655-1721 (dzieło zawierało m.in. utwory J. Barclaya i Marcusa Boxhorna). 
Tak znaczna podaż druków tego rodzaju wynikała z rozwoju szkolnictwa (zwłaszcza jezuickiego) jaki nastąpił w XVII wieku, ale przede wszystkim ze znaczenia, jakie przypisywano sztuce wymowy w całej kulturze badanego okresu.

Podobne wydawnictwa występowały zwykle w takich księgozbiorach jak biblioteki: S. Lubienieckiego, Ł. Opalińskiego, H. Pinocciego, J. Sobieskiego itp. Z ważniejszych pozycji warto wymienić dzieła Lucjusza Seneki Starszego (odnotowane w bibliotece S. Lubienieckiego, znane także $九$. Opalińskiemu i H. Pinoccie$\mathrm{mu}$ ), dzieła Arystotelesa i Cycerona (biblioteka J. Sobieskiego).

Obok dzieł pisarzy antycznych, omawiane księgozbiory zawierały bogate działy traktatów pisarzy nowożytnych, takich jak: Iohann Sturm, loannes Gerard Vossius, lacobus Pontanus, Gerard Pelletier i inni.

W księgozbiorze J. Lorkowskiej znalazło się dzieło Kwintyliana Institutio oratoria natomiast w bibliotekach M. Grabskiego i H. Szembeka prace pisarzy nowożytnych, kolejno: Ars conversandii certis regulis comprehenda Jana Webera i Poeticarum institutionum I. Pontanusa (wszystkie wyżej wymienione dzieła ukazaly się za granica).

\section{b) Zbiory mów}

Wydawnictwa tego typu zawierały m.in. przyklady wystąpień sejmowych. Według B. Nadolskiego tylko nieliczne z nich miały prawdziwie polityczny charakter. Były to takie przemówienia jak: witanie i żegnanie królów, dziękowanie za przyznane urzędy lub dopraszanie się o nie itp. Autorzy mów wywodzili się z reguły spośród dostojników państwowych. Z punktu widzenia niniejszej pracy do najistotniejszych należały - z niżej wymienionych - publikacje Kazimierza Jana Woysznarowicza i Jana Pisarskiego ${ }^{33}$.

Należy tutaj wymienić m.in. Oratora politycznego K.J. Woysznarowicza, wydanego trzykrotnie w latach 1644-1677; Wydwornego polityka Macieja Dobrackiego, pięć wydań z lat 1664-1690; Mówcę polskiego J. Pisarskiego, pięć wydań z lat 1668-1689; Phoenix rhetorum Jana Kwiatkiewicza wydany w trzech edycjach w latach 1672-1720; Famę polską Kazimierza Wieruszewskiego, wydaną trzykrotnie w latach 1720-1730.

Istniał jeszcze jeden rodzaj publikacji omawianego typu, który można określić mianem epistolografii politycznej. Przykładem takich wydawnictw mogą być: Kancelaria polityczna M. Dobrackiego zawierająca zestaw wzorów sporządzania podań, listów, monitów do urzędów państwowych itp. (wydana w czterech edycjach w latach 1665-1690) i Promptuarium epistolographium... Samuela Obodzińskiego z 1665 roku, zawierające wzory listów dyplomatycznych.

Wyżej wymienione publikacje znalazły się w większości bibliotek szlacheckich. Do najpopularniejszych należała praca J. Pisarskiego (biblioteki M. Grabskiego, H. Pinocciego, J. Dzieduszyckiego i J. Sobieskiego). W księgozbiorze S.K. Bieniewskiego odnotowano pracę K.J. Woysznarowicza a w księgozbiorach szlachty krakowskiej niewymieniane dotąd dzieła: Jana Dembińskiego Różne mowy publiczne, sejmikowe i sejmowe wydane w 1727 roku i Wojciecha Bystrzonowskiego Polak sensat z 1730 roku. 


\section{PODSUMOWANIE I WNIOSKI}

Opierając się na danych zawartych w niniejszym opracowaniu, można założyć z dużą dozą ostrożności, że literatura polityczna plasowała się w repertuare wydawniczym lat 1501-1732 zaraz po drukach religijnych i panegirycznych. Podobną tezę zdają się potwierdzać badania M.B. Topolskiej, według której w dziale książki świeckiej o charakterze naukowym wydawanej w Wielkim Księstwie Litewskim, druki historyczne wespół z prawnymi stanowiły $45 \% .{ }^{34}$

Wzrost liczby krajowych wydawnictw omawianego typu nastąpił w drugiej połowie XVIII wieku. Skalę owej zmiany można zobrazować ponownie na przykładzie podaży piśmiennictwa naukowego. Otóż, według A. Żbikowskiej-Migoń wśród publikacji naukowy ch wydanych w Polsce w latach 1750-1820 literatura historyczna stanowiła ok. $13,2 \%$ (484 tytuły) $^{35}$ podczas gdy w latach 1501-1732 ukazało się ok. 1000 tytułów o tematyce historycznej, wśród których dzieła naukowe stanowiły niewielką część.

W świetle powyższych rozważań wypada się zgodzić z J. Tazbirem, że „Literacka kultura europejskiego baroku była oparta przede wszystkim na słowie drukowanym; w Polsce natomiast o wiele znaczniejszą rolę odgrywał rękopis oraz - żywe slowo (...) Wzrostowi liczby druków dewocyjnych i panegirycznych towarzyszył w XVII stuleciu spadek publikacji innego typu (...) ${ }^{36}$

W przypadku poszczególnych dziesięcioleci produkcja wydawnicza nie odbiegala w zasadzie od przeciętnej (10\%). Wzrastała znacznie jedynie w momentach szczególnie skomplikowanej sytuacji społeczno-politycznej państwa. Typowym przykładem jest tutaj burzliwe dwudziestolecie pomiędzy 1571 a 1590 rokiem (okres ugruntowania się ustroju demokracji szlacheckiej w dobie pierwszego bezkrólewia 1572-1573, wojny domowej zwiąanej z elekcją Stefana Batorego i elekcją Zygmunta III, sejmu pacyfikacyjnego z 1589 roku - to najważniejsze wydarzenia polityczne epoki) ${ }^{35}$ Istniał więc bezpośredni związek między życiem społeczno-politycznym kraju a produkcją literatury politycznej. Taki stan rzeczy determinował repertuar wydawniczy w zakresie piśmiennictwa omawianego typu. Miało ono przede wszystkim charakter użytkowy, praktyczny, przeznaczony dla najszerszych rzesz czytelników (oczywiście w skali całego kraju).

Wśród druków o tematyce politycznej zdecydowanie dominują publicystyka (zwraca uwagę fakt, że publikacje w języku polskim stanowity ok. 62\%) i druki informacyjno-propagandowe. Rola publicystyki wzrasta zwłaszcza po 1660 roku, kiedy to spada liczba książek wyprodukowanych przez krajowe oficyny wydawnicze (dotyczy to także publikacji historycznych i teoretycznych traktatów politycznych).

Jednak szczególnie trudny okres, w zakresie produkcji literatury politycznej o „poważniejszym ciężarze gatunkowym", przynoszą lata 1700-1732.

$Z$ analizy danych bibliograficznych wynika, że gros publikacji ujmujących problemy państwa w sposób całościowy, wyczerpujący, powstało na przełomie XVI i XVII wieku i do polowy XVII wieku. O ich niezmiennej popularności w ciagu całego badanego okresu świadczą liczne wznowienia dzieł takich pisarzy jak Piotr Skarga czy Szymon Starowolski. W latach następnych ilość pism tego typu zmniejsza się znacznie wobec wzrostu produkcji druków ulotnych i informacyjno-propagando- 
wych. Te ostatnie tworzą kolejną grupę pod względem liczebności wśród publikacji politycznych. Jako nośniki aktualnych informacji politycznych stanowity stały element repertuaru wydawniczego nie podlegając $w$ zasadzie zmianom (może $z$ wyjątkiem druków o charakterze prasowym, które wraz ze wzrostem zapotrzebowania na nie, nabierały $w$ ciagu XVII wieku coraz więcej cech wydawniczych charakterystycznych dla współczesnych gazet). Treść druków tego typu nawiązywala z reguly do spraw polskich lub z Rzeczpospolitą związanych.

Kolejną grupę stanowiły druki o tematyce historycznej. W okresie staropolskim historii przypisywano „duże wartości utylitarystyczne jako nauce, która dostarczała wiele godnych naśladowania przykładów oraz zbawiennych wskazań politycznych". ${ }^{38}$ Podobny sposób ujmowania historii znalazł swoje odbicie $w$ produkcji wydawniczej badanego okresu. Świadczy o tym zapewne m.in. znikoma ilość krajowych opracowań z zakresu teorii historii. Innym znamiennym przykładem jest duża liczba tytułów z zakresu biografistyki genealogii i heraldyki ( $z$ tym, że dzieła heraldyczne wydawano w zasadzje w pojedyńczych edycjach co mogło wynikać $z$ wysokich kosztów produkcji tego rodzaju wydawnictw).

Na utylitarystyczne funkcje książki historycznej może wskazać także ewolucja krajowego piśmiennictwa historycznego w zakresie tzw. ujęć całościowych i wzrost w XVII wieku ilości publikacji dotyczących dziejów współczesnych. Powyższe stwierdzenia odnoszą się do dziejów rodzimych dominujących wśród wydawnictw o tematyce historycznej.

Drugą co do wielkości grupę wśród publikacji historycznych stanowiły dzieła z zakresu historii antycznej i starożytnictwa. Większość z nich to dzieła klasyków rzymskich. Były to teksty oryginalne ( $w$ wieku XVI opatrone niekiedy komentarzem naukowym) lub tłumaczone na język polski (zwłaszcza w XVII wieku). Funkcje utylitarne tego rodzaju piśmiennictwa wynikały z tego, że teksty starożytne były traktowane jako wzorce stylistyczne, jako źródło wiedzy o świecie doskonalym i według tej wiedzy starano się formułować programy polityczne, wzorce osobowe i nakazy etyczne konfrontując współczesność ze starożytnością. ${ }^{39}$. Preferując antyczny Rzym, krajowi wydawcy wyraźnie pomijali dzieje Grecji i Bizancjum. Inna cecha charakterystyczna tej grupy druków to stosunkowo niewielka liczba nowożytnych opracowań dziejów antycznych, w tym tak przecież popularnych i użytecznych wydawnictw jak zbiory sentencji i aforyzmów.

W przypadku historii krajów europejskich źródła bibliograficzne rejestrująa przede wszystkim pozycje dotyczące krajów ościennych. Wiązało się to być może z podziałem kontynentu na kilka "małych Europ" z których każda żyła własnym życiem politycznym i kulturalnym - zwłaszcza w XVII wieku.

Stosunkowo duża liczba druków poświęcona Turcji potwierdza szczególną rolę polityczną, kulturalną, a także religijną jaką odgrywał ten kraj w świadomości społecznej począwszy od połowy XVI wieku. Istniało przeświadczenie o stałym zagrożeniu tureckim nie tylko dla Rzeczypospolitej ale dla „całego świata chreścijańskiego". Na tym tle zrodziła się idea „przedmurza”, według której ciężar obrony chrześcijańskiej Europy spoczywał na barkach Rzeczypospolitej. Wojny prowadzone z Turcją w XVII wieku utwierdzały ogólne przekonanie o tej specjalnej misji państwa polskiego. Od teorii "małych Europ" odbiega nieco widoczne zaintereso- 
wanie dziejami Francji. Brakowało co prawda całościowych opisów dziejów tego kraju, ale ważniejsze wydarzenia z jego historii (np. wojny religijne) znalazły swoje odbicie w krajowej produkcji wydawniczej.

Najmniejszą grupę stanowiły książki z zakresu historii powszechnej. Były to w zasadzie (zwłaszcza w XVII wieku) dzieje Rzeczypospolitej opisywane w połączeniu z historią państw ościennych.

Kolejny dział piśmiennictwa politycznego to traktaty z zakresu teorii państwa i społeczeństwa. Analiza danych bibliograficznych zdaje się wskazywać na brak szerokiej prezentacji europejskiego dorobku w zakresie nowożytnych koncepcji dotyczących teorii społeczeństwa i państwa. Wśród najwybitniejszych pisarzy politycznych, których twórczość znalazła swoje odbicie wźródłach bibliograficznych do najpopularniejszych należeli: J. Lipsius (popularyzator tacytyzmu i makiawelizmu) i E. Puteanus reprezentujący nowożytne ujęcie tradycyjnych doktryn arystotelesowsko - tomistycznych, a także teoretycy umowy społecznej: Hugo Grotius (nawiasem mówiąc zwolennik poglądu, według którego ustrój Rzeczypospolitej stanowił najlepszą formę władzy) oraz Samuel Pufendorf. Niewielkiej ilości dzieł autorów europejskich towarzyszyl skromny udział twórczości naukowej sensu stricto pisarzy krajowych (w skali kraju - bowiem od przeciętnej krajowej w tej dziedzinie znacznie odbiegał repertuar wydawniczy oficyn pomorskich dzialających w takich ośrodkach jak Gdańsk, Toruń czy Elbląg).

Główny zrąb piśmiennictwa omawianego typu stanowity publikacje o charakterze „emendacyjnym" lączące refleksję teoretyczną nad podstawowymi problemami istoty i organizacji państwa z krytyczną oceną rzeczywistości społeczno-politycznej Rzeczypospolitej. Największa ilość druków tego rodzaju powstała w okresie do połowy XVII wieku, przy czym szczególną popularnością cieszyły się dzieła z przełomu wieku XVI i XVII (S. Orzechowski i J.D. Solikowski).

Następną grupę traktatów politycznych stanowily utwory parenetyczne, z definicji wypełniające funkcje dydaktyczne, użytkowe. $W$ krajowym repertuarze wydawniczym znalazły się przede wszystkim dzieła autorów rodzimych.

Dzieła autorów antycznych reprezentowane były z reguły przez pisarzy rzymskich (wyjąwszy oczywiście prace Arystotelesa czy Demostenesa). Tak jak w przypadku historii antycznej większość oryginalnych tekstów pisarzy starożytnych opublikowano w okresie Renesansu. Od końca XVI wieku coraz częściej pojawiały się tłumaczenia polskie (niejednokrotnie dalekie od oryginału). Również charakterystyczna jest niewielka ilość nowożytnych opracowań starożytnych koncepcji z dziedziny teorii państwa i polityki (warto tutaj jeszcze raz podkreślić widoczne zainteresowanie myśla polityczną Tacyta, które znalazło odzwierciedlenie w piśmiennictwie XVII wieku).

Najmniejszą - co do liczebności - grupą wyodrębnionych publikacji politycznych były podręczniki do nauki wymowy tzn. traktaty retoryczne izbiory mów. Wśród traktatów retorycznych najrzadziej reprezentowane były dzieła klasyków (źródła bibliograficzne odnotowują prawie wyłącznie szesnastowieczne edycje wydawnictw tego typu). Dominują natomiast podręczniki retoryki publikowane z reguły dla potrzeb szkolnictwa polskiego. Po 1660 roku nastapił szczególny wzrost liczby wydań tzw. zbiorów mów, które służyły równocześnie jako podręczniki wymowy i 
jako wydawnictwa źródłowe do nauki dziejów ojczystych. Rozwój piśmiennictwa tego rodzaju wynikał zapewne z tego, że zastępowało ono w pewien sposób poważniejszą literaturę polityczną, której coraz częściej brakowało w drugiej połowie XVII wieku. Należy przypomnieć, że obok niewątpliwego zapotrzebowania na literaturę użytkową (które potwierdzają także dane dotyczące publikacji z zakresu prawa i prawodawstwa, wśród których największą grupę stanowiły druki urzędowe i zbiory praw - ok. 23\% całej literatury polityczno-prawnej) duży wpływ na repertuar wydawniczy miały różne formy mecenatu, cenzura państwowa i duchowna, autocenzura twórców oraz organizacja, struktura $i$ kondycja finansowa krajowego ruchu wydawniczego.

Krajową ofertę wydawniczą poszerzal import książki rozprowadzanej m.in. przez sieć księgarską. Charakterystyczne jest to, że wśród wydawnictw zagranicznych oferowanych czytelnikom przez polskich księgarzy przeważały naukowe edycje tekstów starożytnych, nowożytne ujęcia dziejów antycznych, dzieła z zakresu historii powszechnej i europejskiej - traktaty polityczne i retoryczne, wypełniając $w$ pewnym stopniu luki w produkcji polskich oficyn drukarskich. Należy zaznaczyć, że tak jak w przypadku produkcji drukarskiej od przeciętnej krajowej odbiegała oferta wydawców pomorskich. Można to stwierdzić porównując inwentarze księgarni Jana Chrystiana Laurera „Catalogus quorundam librorum diversum facultatum qui in officina Johannis Laureri venales habitur" z 1692 roku $^{40} \mathrm{czy}$ "Catalogus insignium... librorum officinae Simonis Beckensteinii... bibliopolae Gedanensis" z 1697 roku $^{41}$ - w których obok nielicznych poloników występowało głównie piśmiennictwo obce, w tym dziela najwybitniejszych pisarzy politycznych zarówno szesnasto- jak i siedemnastowiecznych $-z$ inwentarzami księgarni Balcera Hübnera z $1591^{42}$ i Ignacego Antoniego Hebanowskiego $z$ lat $1709-1715^{43}$ (Lwów), Andrzeja Ciechończyka z 1621 roku $^{44}$ (Jarosław) oraz Adama Krypuszowicza z 1653 roku ${ }^{45}$ (Kraków), w których dominują polonika.

W świetle powyższych rozważań nasuwa się pytanie o stopień zależności między repertuarem wydawniczym a zawartością księgozbiorów szlacheckich w zakresie piśmiennictwa politycznego.

Porównując procentowy udzial literatury omawianego typu w ogólnej produkcji książki i badanych księgozbiorach szlacheckich (należy przypomnieć, że w omawianych bibliotekach pozycje o tematyce politycznej stanowity przeciętnie $1 / 3$ wszystkich pozycji, przewyższając liczebnością książki o innej tematyce) można wysnuć wniosek o istnieniu rozbieżności między ofertą wydawniczą krajowych oficyn drukarskich a potrzebami tego kręgu czytelników.

Podobną hipotezę może potwierdzać fakt obecności w badanych księgozbiorach druków obcych i odmienna od panującej w repretuarze wydawniczym hierarchia (według kryteriów ilościowych $i$ jakościowych) poszczególnych grup piśmiennictwa politycznego.

Ze względu na zawartość analizowane księgozbiory szlacheckie można podzielić na dwie zasadnicze grupy:

- księgozbiory z przewagą wydawnictw zagranicznych (biblioteki J. Szembeka, Ł. Opalińskiego, S. Lubienieckiego, A.M. Lubomirskiego, H. Pinocciego, K.T. Drohojowskiego, J. Dzieduszyckiego, J. Stadnickiego i S.K. Bieniewskiego), 
- księgozbiory z przewagą poloników (biblioteki S. Sapińskiego, zapewne J. Lorkowskiej, M. Grabskiego, K. Dobińskiego i księgozbiory omówione przez H. Bogdanow).

Warto w tym miejscu zaznaczyć, że powyższy podział ma charakter umowny, bowiem odnosi się wyłącznie do omawianych księgozbiorów, które z pewnością nie stanowią dostatecznej reprezentacji wszystkich bibliotek szlacheckich badanego okresu. Istniały przecież inwentarze, w których można odnotować wyłącznie pojedyncze pozycje (jak np. inwentarz z 1620 roku, który rejestruje niezidentyfikowaną kronikę polskaj oraz pokaźna grupa szlachty, która jak można sądzić książek w ogóle nie posiadała.

Według R. Weissa: „długie inwentarze wymieniające niekiedy przedmioty o minimalnej wartości, żadnym słowem nie wspominają o książce"A6. Jest to o tyle zrozumiałe, że według K. Dmitruka „wśród magnaterii i bogatej szlachty bylo $28 \%$ analfabetów, wśród średniej szlachty $40 \%$, drobnej $42 \%{ }^{47}$.

Wracając do księgozbiorów omawianych w niniejszej pracy należy zwrócić uwagę na pewną prawidłowość: właściciele bibliotek „pierwszej grupy" wywodzili się w większości z warstwy magnackiej lub środowisk intelektualnych (S. Lubieniecki, $\mathrm{H}$. Pinocci), tworzących elitarny krąg czytelników. Osoby z tego kręgu wyróżniało: wykształcenie (obejmowało studia krajowe i zagraniczne, które znacznie poszerzały zainteresowania i kompetencje czytelnicze) wysoki status społeczno-polityczny i przynależność do elity rządzącej, zamożność (umożliwiająca prywatny import książek).

Właściciele bibliotek "drugiej grupy" byli natomiast przedstawicielami tej warstwy szlachty, której wykształcenie ograniczało się zwykle do odbycia nauki w kolegiach, aktywnej politycznie ale nie obejmującej wyższych urzędów państwowych. Wywodzili się w większości ze szlachty średniej (niekiedy posiadaczami podobnych księgozbiorów byli także magnaci).

Wymienione grupy bibliotek różniły się w pierwszym rzędzie wielkością zbiorów: od kilkunastu, kilkudziesięciu tytulów w przypadku księgozbiorów „drugiej grupy" do kilkuset tytułów w księgozbiorach „pierwszej grupy”.

W większości analizowanych księgozbiorów dominują dzieła historyczne.

Zawartość tematyczna i wielkość działów piśmiennictwa historycznego była odmienna w poszczególnych bibliotekach. I tak np. w księgozbiorach, które służyły jako warsztat pracy intelektualisty, pisarza (S. Lubieniecki, Ł. Opaliński) największą grupę stanowily dzieła z zakresu historii antycznej i starożytnictwa, przy czym obok dziejów starożytnego Rzymu można znaleźć tutaj antyczną historię powszechną, historię Grecji i Bizancjum. W bibliotekach mężów stanu (J. Sobieski, A.M. Lubomirski) dominowala natomiast historia - dawna i współczesna - krajów europejskich. Duży udział piśmiennictwa poświęconego poszczególnym krajom Europy był charakterystyczny dla bibliotek „pierwszej grupy". Zgodnie z renesansowymi tradycjami, szczególnym zainteresowaniem darzono Wlochy oraz Niderlandy i Francję, gdyż jak stwierdził W. Voisé „Szczególnie popularnym krajem wśród intelektualistów badanego okresu (tj. XVII wieku - przypis mój) była Holandia, oaza tolerancji i swobody poglądów... Atrakcyjność Holandii nie umniejszała dominującego znaczenia Francji, język francuski zaś był panującym językiem artystów, literatów i myślicieli" ${ }^{\prime 48}$. Oczywi- 
ście w omawianych księgozbiorach można było znaleźć turcica ale, co należy podkreślić, przeważnie pochodzenia zagranicznego.

Ogólnie mówiąc w działach historycznych omawianych bibliotek przeważało piśmiennictwo o charakterze naukowym (nie zabrakło także tytułów z zakresu teorii historii) najwybitniejszych historyków antycznych i nowożytnych - stąd polonika były tu reprezentowane bardzo rzadko.

Gros poloników rejestrowanych przez te księgozbiory dotyczyło historii Rzeczypospolitej. Obejmowały one podstawowy trzon rodzimego piśmiennictwa historycznego w zakresie wszystkich wyróżnionych typów polskiej książki historycznej. Tytuły odnotowane w inwentarzach księgozbiorów znajduja pełne odzwierciedlenie w repertuarze wydawniczym badanego okresu - jeśli chodzi o pozycje wydawane najczęściej, najpopularniejsze - zwłaszcza w przypadku ujęć całościowych i ujęć poszczególnych fragmentów dziejów Rzeczypospolitej. Powyższe stwierdzenia odnoszą się także do zawartości działów historii ojczystej znajdujących się w księgozbiorach „drugiej grupy”. Piśmiennictwo tego typu stanowiłoby więc płaszczyznę integracji różnych grup szlacheckich, przynajmniej w zakresie doboru lektury historycznej.

$W$ przypadku innych rodzajów piśmiennictwa historycznego w bibliotekach "drugiej grupy" można spotkać prawie wyłącznie wydawnictwa krajowe, przy czym przeważa historia starożytnego Rzymu wobec pojedynczych tytułów z zakresu dziejów powszechnych i europejskich (zwykle turcica).

Kolejny duży dział publikacji politycnych to traktaty polityczne i publicystyka. W księgozbiorach ,pierwszej grupy" występowały przede wszystkim traktaty polityczne - poświęcone teorii państwa i społeczeństwa a udział publicystyki był minimalny (ograniczał się do autorów najwybitniejszych takich jak P. Skarga czy S. Starowolski, pozycji których autorem był właściciel biblioteki np. Polonia defensa w zbiorach $Ł$. Opalińskiego, lub tytułów którymi zbieracz był szczególnie zainteresowany np. Jawnej niewinności manifest J. Lubomirskiego w księgozbiorze A.M. Lubomirskiego).

Działy traktatów politycznych rejestrowane przez biblioteki omawianego typu charakteryzowały się różnorodnością tematyki, zawierając przy tym klasykę europejskiej myśli politycznej - począwszy od starożytności aż po czasy współczesne.

Znalazhy się w nich dzieła reprezentujące zarówno arystotelesowsko-tomistyczną doktrynę $w$ zakresie teorii państwa jak i ideologię absolutną, publikacje nawiązujące do teorii umowy społecznej i dzieła propagujące ideę teokratycznej organizacji państwa. W omawianych księgozbiorach nie zabrakło także pism monarchomachów i utopistów szesnastowiecznych.

Odnośnie metod sprawowania władzy, omawiane księgozbiory - obok najliczniejszych dzieł Tacyta i pokrewnego mu Machiawellego, zakładających konieczność stosowania środków specjalnych, wyjątkowych dla obrony potęgi państwa zawieraly także publikacje zwalczające zasadę tzw. racji stanu.

Podobną wszechstronność można thumaczyć np. skłonnościami komparatystycznymi właścicieli księgozbiorów czy ich otwartością na różne idee, teorie polityczne. Równocześnie należy pamiętać o tym, że epoka w której księgozbiory powstały to okres kultury erudycyjnej, retorycznej, którą cechowało dążenie do rejestracji wszystkich źródeł z danej dziedziny i świadomy eklektyzm. 
Biblioteki tego typu wyróżnia także stosunkowo duża ilość utworów parenetycznych (także autorów krajowych) oraz publikacji poświęconych symbolice, oznakom i gloryfikacji wladzy np. nie wymienione dotąd Idea principis christiano - politico Diego Saavedra Faxardo ksieggozbiory H. Pinocciego, A.M. Lubomirskiego i J. Sobieskiego), Le imprese illustri... Girolamo Rusceli (biblioteka J. Sobieskiego) czy Symbola divina et humana pontificium, imperatorem, regum... J. Typotiusa (księgozbiór A.M. Lubomirskiego).

Tak jak w przypadku dzieł historycznych, księgozbiory "pierwszej grupy" rejestrują pośród poloników przeważnie dzieła najważniejsze, m.in. A.F. Modrzejewskiego, S. Orzechowskiego, Ł. Górnickiego, B. Keckermanna, S. Starowolskiego, Aarona Aleksandra Olizarowskiego autora De politica hominum societate... czy A.M. Fredry.

Z polskich tłumaczeń znalazły się tutaj m.in. Polityka Aristotelesowe... S. Petrycego i Polityca pańskie J. Lipsiusa; natomiast z krajowych wydań dzieł autorów obcych np. Civilis doctrinae Eryka Puteanusa.

Wyżej wymienionych autorów polskich można także spotkać w księgozbiorach "drugiej grupy". Ich prace uzupełniają dzieła autorów starożytnych wydane w kraju oraz nieliczne pozycje zagraniczne, które miały zapewne rekompensować niklą produkcję wydawniczą krajowych oficyn drukarskich jak np. nowożytne opracowania myśli politycznej antyku - jedyną książką z tej dziedziny jaka znalazła się w księgozbiorze M. Grabskiego było Alphabetum politicum: observata politica ad. C. Sueton. Tranquilli... Amsterdam 1630 lub 1637 J. Jerecote'a. Ogólnie mówiąc występowały tutaj wszystkie rodzaje piśmiennictwa politycznego omawianego typu.

W odróżnieniu od księgozbiorów „pierwszej grupy” w księgozbiorach S. Sapińskiego i M. Grabskiego znalazły się w stosunkowo dużej liczbie druki publicystyczne. W przypadku druków informacyjno-propagandowych, ich liczba ksztaltuje się różnie w poszczególnych księgozbiorach. Trudno jest określić prawdopodobną ilość piśmiennictwa tego rodzaju w księgozbiorach badanego okresu zważywszy, że w inwentarzach ruchomości podawano zwykle książi o dużej wartości rynkowej, do których druków propagandowych zaliczyć nie można. W częściowo zachowanym inwentarzu $Ł$. Opalińskiego poza wyjątkami - Censura candidatorum... A. Olszowskiego - brakuje tego typu pozycji chociaż wiadomo, że chętnie zaopatrywał się np. w tzw. nowiny. Najwięcej tego typu druków rejestrują inwentarze księgozbiorów S. Sapińskiego i N. Grabskiego a z bibliotek „pierwszej grupy” H. Pincocciego (wydawcy „Merkuriusza Polskiego") i A.M. Lubomirskiego. Spośród utworów propagandowych do najczęściej spotykanych należały pisma antytureckie (w księgozbiorach pierwszej grupy także zagraniczne). Jeśli chodzi o relacje, nowiny itp. charakterystyczne jest to, że obok poloników w bibliotekach "pierwszej grupy" występowały druki obce.

Ostatnią grupę książek jaką należy omówić, stanowią traktaty retoryczne i zbiory mów. Charakter piśmiennictwa tego typu występującego w badanych księgozbiorach potwierdza ogólne prawidłowości określone w niniejszym opracowaniu. Księgozbiory „pierwszej grupy” w przeważającej części zawierały traktaty retoryczne pisarzy antycznych i nowożytnych, które nie miały zazwyczaj krajowych edycji. Podobnie ma się rzecz ze zbiorami sentencji i aforyzmów oraz dzieł z zakresu 
epistolografii (najliczniejszą grupę tytułów poświęconych epistolografii zawierała biblioteka $\mathrm{H}$. Pinocciego, co było zapewne związane z funkcją sekretarza królewskiego i dyplomaty jaką pełnił).

Obie, wyróżnione grupy bibliotek posiadały natomiast przynajmniej jeden zbiór mów polskich. W księgozbiorach "drugiej grupy" znalazły się ponadto traktaty retoryczne autorów krajowych oraz co znamienne pojedyncze druki zagraniczne.

Podsumowując należy stwierdzić, że właściciele bibliotek, których można zaliczyć do elitarnego kręgu czytelnków nie korzystali raczej z oferty krajowego ruchu wydawniczego zaspokajając swe rzeczywiste lub wyimaginowane potrzeby poznawcze głównie przez lektury obce (okres XVII wieku nie był pod tym względem wyjątkowy na co wskazują m.in. badania A. Żbikowskiej-Migoń) ${ }^{49}$. O charakterze księgozbioru nie decydowyła wyłącznie przynależność warstwowa właściciela (obok magnaterii wśród właścicieli księgozbiorów „pierwszej grupy” można znaleźć także przedstawicieli szlachty średniej np. S. Lubieniecki i nobilitowanego mieszczanina $\mathrm{H}$. Pinocciego). Powyższa konstatacja dotyczy także księgozbiorów „drugiej grupy”, których właściciele reprezentują raczej czytelnika masowego.

Innymi słowy przynależność warstwowa czy stanowa (zwraca uwagę obecność w inwentarzach księgozbiorów patrycjatu krakowskiego dzieł najwybitniejszych pisarzy europejskich) ${ }^{50}$ odgrywała mniejszą rolę niż: wykształcenie, kompetencje czytelnicze, predyspozycje intelektualne $i$ indywidualne preferencje czytelnika, związane często z jego twórczością literacką (H. Pinocci) czy funkcjami męża stanu (m.in. S.K. Bieniewski, A.M. Lubomirski, J. Sobieski).

Natomiast płaszczyzną integracji ruchu wydawniczego z księgozbiorami „pierwszej" jak i „drugiej” grupy były charakter piśmiennictwa politycznego epoki tzn. jego typologia tematyczna oraz obecność w badanych księgozbiorach najczęściej wydawanych poloników.

Kolejnym elementem łączącym produkcję wydawniczą ze strukturą tematyczną księgozbiorów była praktyczno-użytkowa funkcja książki politycznej w badanym okresie (wiązało się to z ogólną tendencją epoki, wyrażającą się w przywiązaniu do utylitarnych wartości książki).

Kapitalnym przykładem jest podręczny księgozbiór S.B. Bieniewskiego, z którym właściciel jechał na sejm 1659 roku. Wśród 31 tytułów znalazły się pisma historyczne (dzieje starożytne, europejskie i historia Rzeczypospolitej), traktaty polityczne, zbiory mów i wzory listów. Bieniewski, jeden z twórców ugody hadziackiej, miał się na tym sejmie zajmować problemami kozaczyzny i kościoła greckokatolickiego, co znalazło pełne odzwierciedlenie w jego księgozbiorze.

Z funkcją praktyczno-użytkową łączyła się tutaj funkcja informacyjno-propagandowa książki politycznej (niezwykle istotna $w$ literaturze staropolskiej) umożliwiająca dobrą orientację w sytuacji społeczno-politycznej w skali lokalnej i całego kraju lub poza jego granicami (księgozbiory „pierwszej grupy”).

W przypadku funkcji ideologicznej sytuacja wydaje się bardziej skomplikowana. Analizując produkcję wydawniczą literatury politycznej można wyodrębnić trzy główne nurty piśmiennictwa politycznego, wyróżnione ze względu na stopień akceptacji ideologii szlacheckiej i modelowych rozwiązań ustrojowych państwa. 
Pierwszy z nich, reprezentowany m.in. przez twórczość M. Bielskiego, $H$. Stryjkowskiego, A. Gwagina, S. Sarnickiego czy Chlebowskiego odnosił się bezkrytycznie do ideologii szlacheckiej, ideowych założeń funkcjonowania państwa i ich praktycznej realizacji.

Drugi nurt reprezentowany był przez takich pisarzy jak S. Orzechowski, J.D. Solikowski, J. Wereszczyński, A.M. Fredro i inni. Aczkolwiek w pełni akceptował urządzenia ustrojowe Rzeczypospolitej, uważając je za idealne ponieważ oparte na prawach i przywilejach szlachty (z naczelną zasadą „złotej wolności” włącznie) traktowanej jako główny podmiot w życiu społeczno-politycznym państwa, to jednak odnosiły się w sposób krytyczny do otaczającej go rzeczywistości. Sprzeczność praktyki z teorią tłumaczono tutaj przede wszystkim zanikiem w świadomości szlachty konieczności istnienia równowagi między prawami jednostki czy warstwy a jej obowiązkami względem państwa, lub demoralizacją stanu szlacheckiego. Ów nurt dążył do socjalizacji szlachty, stworzenia z niej społeczeństwa obywatelskiego, na którym spoczywa pełnia odpowiedzialności za funkcjonowanie państwa (liczba wydań i ich zasięg chronologiczny wskazuje na największą popularność tego nurtu).

Za uszczupleniem prerogatyw stanu szlacheckiego na rzecz wzmocnienia władzy królewskiej wypowiadali się m.in. A. Frycz Modrzewski, M. Kromer, K. Warszewicki, P. Skarga, S. Petrycy, Ł.Górnicki, S. Starowolski, J. Ossoliński, A.A. Olizarowski czy S.H. Lubomirski. Wielu z wymienionych pisarzy widziało także potrzebę rozszerzenia kompetencji senatu kosztem izby poselskiej (podobny punkt widzenia reprezentowali także nie wymienieni dotąd W. Goślicki i Stanisław Karnkowski autor De primatu senatorio Regini Poloniae z 1593 roku).

Omówione powyżej kierunki polskiej myśli politycznej łączyło - z wyjątkami przywiązanie do katolicyzmu jako religii panującej państwa, w którym Kościół miałby sprawować nadrzędną rolę (S. Orzechowski, J.D. Solikowski, J. Werszyński, K. Warszewicki, P. Skarga, S. Starowolski i inni).

Kolejna płaszczyzna integracji to generalna aprobata (z wyjątkiem P. Skargi, który był „zdecydowynym zwolennikiem monarchii absolutnej" ${ }^{51}$ ) systemu politycznego Rzeczypospolitej opartego na symbiozie instytucji republikańskich i monarchistycznych oraz oligarchicznych tzn. senatu określanego jako stan pośredni inter majestatem et libertatem.

Nareszcie, wszystkich wymienionych pisarzy łączyło rozpatrywanie problematyki związanej z życiem społeczeństwa w kategoriach moralnych (zgodnie z ujęciem chrześcijańskim cnota odgrywała tutaj ogromną rolę).

Z wcześniejszych rozważań wynika, że w badanych księgozbiorach znalazły się dzieła pisarzy najwybitniejszych lub najpopularniejszych, tworzące kanon literatury politycznej XVI i XVII wieku. Niosły one różne treści ideowe. Jako przykład może posłużyć księgozbiór M. Grabskiego, w którym obok prac S. Orzechowskiego, J.D. Solikowskiego i A.M. Fredry znalazły się dzieła M. Kromera i S. Starowolskiego. Nie zabrakło także apologii A. Korycińskiego. Zgodnie z duchem epoki księgozbiór rejestruje także dwa dzieła Tacyta.

Z podobną sytuacją można spotkać się także w księgozbiorach „pierwszej grupy" bogatszych o europejski kanon literatury politycznej. Trudno w tej sytuacji 
przesądzać o specjalnych preferencjach ideologicznych poszczególnych właścicieli bibliotek.

I tak np. nie można jednoznacznie wnioskować o szczególnej aprobacie idei mocnej władzy królewskiej na podstawie dużej popularności dzieł J. Lipsiusa, które odbierano w Polsce jako pochwałę władzy autorytarnej (o czym świadczą m.in. słowa Jan Zamoyskiego „Jesteś Wasza Królewska Mość summus, a my członkami nie posesją W. Królewskiej Mości... Nie tak jako Lipsius pisze, który chce, aby wszystka autoritas przy królu zostawała..."52), bowiem te jako klasykę po prostu należało znać niezależnie od osobistych preferencji ideologicznych czytelnika.

Innymi słowy potencjalne funkcje ideologiczne książki politycznej można określić tylko na podstawie szczegółowych badań z zakresu czytelnictwa, wykraczających poza ramy niniejszego opracowania.

Literatura polityczna okresu staropolskiego wypełniała również funkcję poznawczą a takze prestiżową.

Wartości poznawcze krajowej literatury politycznej obejmujące wiedzę o polityce, państwie i społeczeństwie mogły być wystarczające tylko dla właścicieli księgozbiorów „drugiej grupy” nie zaspakajały natomiast potrzeb właścicieli księgozbiorów "pierwszej grupy".

Nie bez znaczenia był tu także czynnik prestiżowy, bowiem wydaje się, że raczej więcej prestiżu przynosiły znajomość i posiadanie literatury obcej aniżeli rodzimej, co można uznać za kwintesencję rozważań nad stosunkiem elitarnego kręgu czytelników do krajowej produkcji wydawniczej w zakresie literatury politycznej.

\section{Przypisy}

${ }^{1}$ B. Bieńkowska, Inwentarze księgozbiorów prywatnych jako źródia do badań nad dziejami czytelnictwa, „Studia o Książce" 1989, s 69-71.

2 Praca magisterska napisana pod kierunkiem prof. dr hab. Barbary Bieńkowskiej w Instytucie Bibliotekoznawstwa i Informacji Naukowej Uniwersytetu Warszawskiego w 1989 r. Maszynopis Bibl. IBilN sygn. 1307.

${ }^{3}$ J. Maciszewski, Szlachta polska i jej państwo, Warszawa 1985, s. 152

${ }^{4}$ C. Hernas, Literatura Baroku, Warszawa 1987, s. 20-21.

${ }^{5}$ M. Koza, Z księgozbiorów szlacheckich w Wielkopolsce XVII w., "Roczniki Historyczne" 1934, s. $179-180$.

${ }^{6}$ K. Schuster, Biblioteka Łukasza Opalinskiego marszalka nadwornego koronnego (1612-1662), Wroclaw 1971 , s. 180-257.

7 J. Tazbir, Księgozbiór Stanisiawa Lubienieckiego, "Rocznik Biblioteki Narodowej” 1968, s. 197-223.

8 J. Skoczek, Lwowskie inwentarze biblioteczne w epoce Renesansu, Lwów 1939, s. 420-425.

9 J. Długosz, Księgozbiór Aleksandra Michaia Lubomirskiego w świetle inwentarza z 1678 r., "Ze Skarbca Kultury" 1972, s. 197-223.

${ }^{10} \mathrm{P}$. Buchwald-Pelcowa, Inwentarz biblioteki Macieja Grabskiego (z zagadnień czytelnictwa w drugiej polowie XVII w.), „Rocznik Biblioteki Narodowej" 1966, s. 318-337.

${ }^{11}$ K. Targosz, Hieronim Pinocci. Studium z dziejów kultury naukowej w Polsce w XVII wieku, Wroclaw 1967. 
12 J.T. Lubomirski, Katalog książek bibliotek najjaśniejszego, najpotężniejszego króla polskiego z Bożej Łaski, Jana III Sobieskiego, szczęśliwie panującego, spisany w 1689 r. Kraków 1879; I. Komasara, Jan III Sobieski - miłośnik ksiąg, Wroclaw 1982.

${ }^{13}$ T. Strzembosz, Jan Strzembosz (1545-1606). Jego rękopis i księgozbiór, "Roczniki Biblioteczne" 1959 , s. $401-423$.

${ }^{14}$ Szkice z dziejów dawnej Bydgoszczy XVI-XVIII w., Bydgoszcz 1975, s. 128-131.

${ }^{15}$ K. Koza, op. cit., s. 281.

16 J. Partyka, Rękopiśmienne księgi szlacheckie - źródla i inspiracje, (W:) Staropolska kultura rękopisu, Warszawa 1990 s. 83-84.

17 K. Schuster, O Drohojowskich w zwiazku z inwentarzem książek z 1676 r., "Rocznik Zakladu im. Ossolińskich" 1974, s. 69-86; K. Schuster, O autorstwie rejestru ksiag z roku 1676 i ich właścicielu Krzysztofie Tomaszu Drohojowskim, „Ze Skarbca Kultury” 1977, s. 43-62.

${ }^{18}$ W. Jablońska, Inwentarze i katalogi biblioteczne w zbiorach rękopiśmiennych Biblioteki Zakladu im. Ossolińskich, „Ze Skarbca Kultury” 1969, s. 111-153.

${ }^{19}$ H. Bogdanow, Literatura spoleczno-polityczna jako wyraz zainteresowań szlachty krakowskiej w XVIII wieku, „Studia o książce" 1973, s. 345-374

${ }^{20}$ K. Estreicher, Bibliografia polska XV-XVIII wieku t. 12-34, Kraków 1939; L. Jarzębowski, F. Jurewicz, Polonika nie umieszczone w Bibliografii Polskiej Estreicherów, wiek XVII. Ze zbiorów Biblioteki Glównej UMK w Toruniu, "Zeszyty Naukowe Uniwersytetu Mikołaja Kopernika w Toruniu. Nauki Humanistyczno-Spoleczne" 1969, s. 99-226; Polonica XVI do XVII wieku nie znane bibliografii Estreichera ze zbiorów Biblioteki Gdańskiej, Zesz. 1-3. Gdańsk 1960-1980; J. Berger-Mayerowa, Nie znane Estreicherowi "polonica" i "silesiaca” w starodrukach Biblioteki Śląskiej, z. 1.2, Katowice 1961; H. Sadowska, Nie znane Estreicherom polonica w zasobie starych druków Biblioteki Uniwersyteckiej we Wroclawiu, "Roczniki Biblioteczne" 1958, s. 38; J. Nowak Dłużewski, Bibliografia staropolskiej okolicznościowej poezji politycznej XVI-XVIII wieku, Warszawa 1964; K. Zawadzki, Gazety ulotne polskie i Polski dotyczące XVI-XVII wieku, t. 1-2, Wroctaw 1977-1984; Dramat staropolski: Od początków do powstania sceny narodowej. Bibliografia, Warszawa 1965; J. Okoń, Dramat i teatr szkolny. Sceny jezuickie XVII wieku, Wroclaw 1970; Bibliografia Literatury Polskiej "Nowy Korbut", t. 2-3, Warszawa 1964-1965.

${ }^{21}$ M. Czarnowska: llościowy rozwój polskiego ruchu wydawniczego 1501-1965, Warszawa 1967.

22 Przy analizie treści druków polskich były pomocne: Literatura polska, Red. J. Krzyżanowski, Warszawa 1984; Historia nauki polskiej, t. 1-2 i 6, Red. B. Suchodolski, Wroclaw 1970; Filozofia i myśl spoleczna XVII wieku, Oprac. Z. Ogonowski, t. 2, Warszawa 1979; C. Hernas, Barok, Warszawa 1979.

Do analizy dzieł autorów europejskich wykorzystano opracowania: Wielka literatura powszechna, Warszawa 1931; K. Grzybowski, Historia doktryn politycznych i prawnych, Warszawa 1967; W. Voisé, Myśl spoleczna XVII wieku. Warszawa 1970, K. Morawski, Zarys literatury rzymskiej, Kraków 1922; T. Sinko, Literatura grecka, Kraków 1932.

${ }^{23}$ Z. Staniszewski, Estetyka polskiego druku ksiażkowego XVIII wieku, "Ze Skarbca Kultury" 1960 , 5. 150 .

24 J.W. Zawisza, Panegiryczny druk okolicznościowy epoki stanisławowskiej, Wroclaw 1980, s. 116.

25 Historia nauki polskiej, t. 3, Wroclaw 1970, s. 163.

${ }^{26}$ W. Jabłońska, op. cit., s. 123-125.

${ }^{27}$ P. Buchwald-Pelcowa, op. cit., s 330

${ }^{28} \mathrm{H}$. Olszewski, Myśli o państwie Samuela Pufendorfa, (W:) Wladza i spoleczerístwo w XVI i XVII wieku, Warszawa 1989, s. 116-136.

29 K. Schuster, Biblioteka tukasza Opalińskiego... s. 19-20.

${ }^{30}$ W. Czapliński, J. Diugosz, Życie codzienne magnaterii polskiej w XVII wieku. Warszawa 1976, s. 152. 
${ }^{31}$ H. Bogdanow, op. cit. 5. 352.

${ }^{32}$ R. Montusiewicz, Kultura retoryczna kolegiów w XVII i połowie XVIII wieku. Rekonesans materiatowy, (W:) Retoryka a literatura, Wroctaw 1984, s. 196.

${ }^{33}$ B. Nadolski, Wymowa XVII wieku, (W:) Barok, Warszawa 1987, s. 339.

${ }^{34}$ M.B. Topolska: Czytelnik i książka w Wielkim Księstwie Litewskim w dobie Renesansu i Baroku, Wroclaw 1984, s. 27.

${ }^{35}$ A. Żbikowska-Migoń, Książka naukowa w kulturze polskiego oświecenia, Warszawa Wroclaw 1977. S. 59 .

${ }^{36} \mathrm{~J}$. Tazbir, Szlachta iteologowie. Studia z dziejów polskiej kontrreformacji, Warszawa 1987, s. 58-59.

37 J.A. Gierowski, Historia Polski 1505-1764, Warszawa 1982, s. 109-131.

${ }^{38}$ K. Schuster, Biblioteka kukasza Opalińskiego..., s. 102.

39 S. Grzeszczuk, Renesans, (W:) Okresy literackie, Warszawa 1983, s. 56-57.

${ }^{40}$ Oferta księgarska J.Ch. Laurera zamieszczona byla przy: Mercator Bernard „Nucleus catecheticus continens brevi compendio doctrinam fidei... erutus", Coloniae 1692, BUW 4g. 11.9.15.

${ }^{41}$ Gdańsk 1697.

${ }^{42}$ W. Łoziński, Leopolitana, "Kwartalnik historyczny” 1890, s. 454-455.

${ }^{43}$ Ł. Kurdybacha, Ksiegarnia Ignacego Antoniego Hebanowskiego we Lwowie 1704-1715 (W:) Pisma Wybrane, t. 3, Warszawa 1976, 5. 89-124.

${ }^{44}$ A. Lewicka Kamiríska, Inwentarz księgarni Andrzeja Cichończyka w Jaroslawiu z r. 1621, "Roczniki Biblioteczne" 1961, s. 253-299.

45 R. Żurkowa, Ksieggarnia Adama Krypuszowica, "Rocznik Biblioteki Polskiej Akademii Nauk w Krakowie" 1989, s. 41-60.

${ }^{46}$ R. Weiss, Wielkopolski dworek szlachecki i jego otoczenie w drugiej polowie XVII wieku (1665. 1666), „Roczniki Historyczne" 1934, s. 92.

47 K. Dmitruk, Sytuacje komunikacyjne w kulturze literackiej dawnej Polski, W: Z dziejów życia literackiego w Polsce XVI $\mathrm{X}$ XVII, Wroctaw 1980, s. 34.

${ }^{48}$ W. Voisé, Myśl spoteczna... s. 40.

${ }^{49}$ A. Żbikowska-Migoń, op. cit., s. 148

50 R. Zurkowa, Literatura polityczna w księgozbiorach mieszczan krakowskich XVII w. "Studia o Książce" 1977, s, 63-83.

51 W. Czaplińskl, O Polsce siedemnastowiecznej, Warszawa 1966, s. 71.

52 Tamże, s. 78. 